\title{
Notes
}

\section{Blacklisting Through the Official Publication of Congressional Reports}

In order to facilitate efficient and responsive administration of government, information must be freely available to all government agencies and to the general public. In furtherance of this goal, the Government Printing Office, upon routine order of either House, prints several thousand copies of all non-confidential reports produced by the component bodies of Congress and distributes them to legis. lators, the Library of Congress, state libraries, other designated depositories, ${ }^{1}$ and any member of the public who requests a copy. On October 28, 1970, for the first time in history, a federal court in the case of Hentoff $v$. Ichord ${ }^{2}$ permanently enjoined the printing of one of these official government reports. The House of Representatives promptly ordered that a slightly modified version of the enjoined report be printed and distributed despite the injunction, and restrained the courts from further interference with such publication. ${ }^{3}$

The subject of these extraordinary events is, in its present form, House Report 91-1732, "Report of Inquiry Concerning Speakers' Honoraria at Colleges and Universities." It is, in popular terms, a blacklist" of "subversive elements" in our society. The document resulted from a survey of guest speakers on the nation's college campuses

1. 44 U.S.C. $\S \S 701,1718,1719$ (1970).

2. 318 F. Supp. 1175 (D.D.C. 1970).

3. See p. 191 infra.

4. House Comm. on INTERnal Security, Report of Inouiry Concerning Speakers' Honoraria AT Colleges and Universities, H.R. Doc. No. 1732, 91st Cong., 2d Sess. (1970) [hereinafter referred to as H.R. 91-1732]. This is a slightly modified version of an carlier report, House COMM. ON INTERNAL SECURITY, LiMired SURVEY OF HONORARIA Given SPEAKERS FOR ENGAGEMENTS at COLleges AND UNIVERSITIES, H.R. Doc. No. 1607, 91st Cong., 2d Sess. (1970) [hereinafter referred to as H.R. 91-1607], which was the document under examination in the Hentoff case. After the injunction against publication of H.R. 91-1607, the House ordered that report published in a slightly altered form and under the new title and designation cited above. For the nature of these alterations, see note 18 infra. All footnote citations are to the modified version, H.R. 91-1732.

5. For purposes of this Note, the term "blacklist" is used to denote a document which attributes widely unpopular political beliefs or associations to specified individuals or organizations. Since the expression is not a legal term of art, factors such as the mo. tivation prompting a document's publication are not included in this definition, although they may be relevant to the constitutionality of such publication. See pp. 215. 23 infra. Moreover, despite the term's negative connotations, it is used here not as a means of suggesting a legal conclusion but rather as a simple, shorthand method of delimiting the subject matter under consideration. 
undertaken in the spring of 1970 by the House Internal Security Committee. ${ }^{6}$ The survey's purpose was to determine the extent to which "persons whom we know to be associated with revolutionary groups" were using college speaking engagements as a means of financing their organizations. Drawing upon lists of guest speakers voluntarily supplied by eighty-three American colleges and universities, ${ }^{8}$ and basing its judgments on undisclosed but allegedly "public source material,"0 the Committee determined that sixty-five of these speakers, including such national figures as Linus Pauling, Benjamin Spock, Muhammed Ali and Dick Gregory, were members or supporters of allegedly revolutionary organizations.10 Although admittedly unable to determine if any of the honoraria received actually inured to the benefit of those organizations, ${ }^{11}$ the Committee proceeded to draft a report based on the survey. That document lists by name the selected individuals, characterized as "Pied Pipers of pernicious propaganda,"12 and specifies the honoraria that each had received from college speaking engagements over the prior two years and the groups with which each was thought

6. Formerly known as the House Committee on Un-American Activities, the Committee was renamed in 1969 by H.R. Res. 89, 91st Cong., 1st Sess., 115 Cosc. Rrc. 3723. 24 (1969).

7. H.R. 91-1732, at 3 .

8. In June of 1970 , the Committee mailed letters to 179 sclected educational institu. tions requesting that they furnish "information with regard to honorariums paid to all guest speakers other than academicians and lecturers who appeared in connection with courses of instruction" during the 1968-70 school years. Specifically, the institutions were asked to list all such speakers by name, designate their "group identification or sponsorship," and describe the manner, amount, source and recipient of exch honorarium payment. Of the 179 institutions solicited, 138 replied. Of these, eighty-three supplied at least some of the requested information, forty-four were unable to comply cither because of administrative difficulties or because they had had no non-academic speakers during the specified period, three requested an extension of time, and only cight explicitly refused to cooperate. H.R. 91-1732, at 5-6. It should be noted that since subpoenas had not been issued, these institutions were under no legal obligation to supply this information.

9. H.R. 91-1732, at 7.

10. Id. at 7-9. For the purpose of this survey, the Committee selected thirteen organizations as relevant to an inquiry into the funding of "revolutionary groups": the Black Panther Party, the "Chicago Seven," the Communist Party, U.S.A. (and associated youth groups), the Nation of Islam, the National Committee to Abolish HUAC (which was omitted in the modified version of the report, see note 18 infra), the National Mfobiliza. tion Committee to End the War in Vietnam, the New Mrobilization Committec to End the War in Vietnam, the Progressive Labor Party, the Socialist Workers Party, the Spring Mobilization Committee to End the War in Vietnam, the Students for a Demo. cratic Society, the Student Mobilization Committee to End the War in Victnam, the Student Non-violent Coordinating Committee, the Young Socialist Alliance, the Youth International Party (Yippies), and the Workers' World Party. See H.R. 91-1732, at 7. These organizations were discussed at length in a separate Appendix to the report, and were variously characterized as "Communist-dominated," "extremist," threats to internal security, and composed of "hoodlum-type revolutionaries." See H.R. 91-1732, at 26-34. This Appendix may itself represent an unconstitutional blacklist, not of the selected speakers but of the organizations themselves.

I1. Id. at 10 .

12. Hentoff v. Ichord, 318 F. Supp. 1175, 1178 (D.D.C. 1970). 
to be associated. ${ }^{13}$ On October 14, 1970, this report was filed with the House of Representatives, which ordered that it be submitted to the Government Printing Office for official publication. ${ }^{44}$

One day earlier, Nat Hentoff, a prominent journalist and one of the sixty-five listed speakers, instituted a class action suit on behalf of all those named in the report, requesting an injunction against dissemination of the report by the Public Printer, the Superintendent of Documents, or any member of the Internal Security Committee. Injunctive relief was sought on the grounds that publication threatened the plaintiffs with irreparable harm by infringing and chilling their First Amendment rights of expression and association. The district court refused to enjoin the congressional defendants, holding that they were immune from such restraint under the speech and debate clause of the Constitution. ${ }^{15}$ It granted the injunction as to the named agents of Congress, however, holding that:

If a report has no relationship to any existing or future proper legislative purpose and is issued solely for sake of exposure or intimidation, then it exceeds the legislative function of Congress; and where publication will inhibit free speech and assembly, publication and distribution in official form at government expense may be enjoined. This is such a report. ${ }^{16}$

Despite the fact that the çourt order enjoined publication of the offending report "or any portion, restatement or facsimile thereof," ${ }^{17}$ Chairman Richard Ichord of the Internal Security Committee resubmitted the report, with only minor alterations, ${ }^{18}$ to the House of Rep-

13. The findings are actually presented in two separate lists: the first stating the date and honorarium for each speech by a selected individual, and the second repeating that information under subheadings indicating the organizations with which each speaker is said to be "identifiable" as an "officer, member or supporter." H.R. 91-1732, at 7.15.

14. 116 ConG. REc. E9646-47 (daily ed. Nov. 17, 1970).

15. Hentoff v. Ichord, 318 F. Supp. $1175,1179.80$ (D.D.C. 1970).

16. Id. at 1182 .

17. Id. at 1183 .

18. Chairman Ichord has openly declared that H.R. 91-1732 is merely a "restatement" of the enjoined H.R. 91-1607, which would appear to make its publication a direct violation of the court order. See 116 Cong. REc. H11615 (daily ed. Dec. 14, 1970) (remarks of Congressman Ichord). The only significant changes in the new report were the de. letion of eight individuals and one organization from the lists and the addition of Appendix IV, which consists of a Defense Department analysis of violent acts com. mitted against campus ROTC facilities during the 1968.70 school years. The deletions were probably made for public relations reasons, since the names dropped were those of Dr. Linus Pauling, a Nobel laureate physicist, and seven members of the National Committee to Abolish HUAC, the inclusion of whom might have been viewed as a trifle self-serving. The addition of the ROTC vandalism study was cvidently made in order to give a post-hoc legitimacy to the report as a whole, since such vandalism would be an obviously legitimate target for congressional legislation for which the report 
resentatives. On December 14, 1970, the House, by resolution, ordered the Public Printer to publish this modificd version and restrained all persons, "whether or not acting under color of office," from interfering with that publication.19

When the modified report was submitted to the House, plaintiffs promptly sought an injunction against its publication as well, but the district court, deciding to avoid further intervention pending review of its original decision, denied the request. ${ }^{20}$ Ironically, that denial itself prevented review of the Hentoff opinion. Since the allegedly damaging information had already been made public, thereby satisfying the purposes of Congress and probably rendering the case moot, the Hentoff defendants decided not to pursue an appeal from the original order granting the injunction. ${ }^{21}$ The two important legal questions raised by the Hentoff case therefore remain unresolved: (I) Do courts have the power to provide relief for injuries arising from the official publication and dissemination ${ }^{22}$ of a congressional report? (2) Are there any constitutional limitations on the power of Congress to publish, in the form of official government reports, blacklists which detrimentally affect an individual's freedoms of expression and association?

\section{The Availability of a Judicial Remedy}

The defendants in Hentoff maintained that both the separation of powers doctrine and the speech and debate clause ${ }^{23}$ provide absolute bars against judicial interference with the official publication of con-

might claim to be useful. See 116 CoNG. REc. H11619 (daily ed. Dec. 14, 1970) (remarks of Congressman Ichord); H.R. 91-1732, at 17. That addition probably has agsravated the report's threat to the First Amendment freedoms of the listed speakers, for the report as a whole now implies that they bear responsibility not only for campus violence in general but also for the particular acts of destruction deseribed in Appendix IV. See H.R. 911732 , at $16-17$.

19. H.R. Res. 1306, 91st Cong., 2d Sess., 116 CoNc. REc. H11608 (daily ed. Dec. 14, 1970).

20. See 116 Conc. REc. HI1620-21 (daily ed. Dec. 14, 1970).

21. The noncongressional defendants, against whom the original Hentoff injunction had been issued, had filed an appeal shortly after the opinion was handed down. After the House ordered publication of the modified report and the district court refused to enjoin that publication, however, the defendants moved to dismiss their own appeal. Motion to Dismiss Appeal, Hentoff v. Ichord, No. 24781. The Court of Appeals for the District of Columbia Circuit granted that unopposed motion. Id. (D.C. Cir. Aug. 19, 1971). Copies of appellants' motion to dismiss and the resulting court order are on file with the Yale Law Joumal.

22. Although the Hentoff court enjoined the publication of the report then at issuc, the source of the harm-and therefore of concern-is the public distribution of the document, not its mere physical reproduction on paper. Throughout this Note, therefore, the term "publication" will be used to denote both reproduction and public dissemination of the material.

23. U.S. CoNsT. art. I, §6. 
gressional reports. ${ }^{24}$ If either contention is correct, the courts would be required to dismiss all claims seeking relief against the official publication of congressional blacklists, leaving the victims without a legal remedy. However, judicial power in this area is not as limited as the Hentoff defendants suggested.

\section{A. The Separation of Powers}

If a government of co-equal branches is to function effectively, those branches must successfully balance the need to check one another's excesses against the danger of undue interference with the others' legitimate functions. In order to achieve this balance, courts have developed the separation of powers doctrine, which is designed in part to prevent the judiciary from considering controversies or undertaking policy judgments that are more appropriately decided by one of the two elected branches of government. ${ }^{25}$

24. 116 Cong. REC. E9647-50 (daily ed. Nov. 17, 1970) (Defendant's Memorandum of Points and Authorities in Opposition to Plaintiff's Motion for a Preliminary Injunction and in Support of Defendant's Motion to Dismiss). The defendants also argued that, even if these two legal principles failed to bar all judicial remedies, their own First Amendment rights of expression would protect them from any sanction for their role in publishing congressional reports. Like the Hentoff proceedings, this Note deals only with the official publication of blacklists at the order of Congress or onc of its subordinate bodies. To the extent that individual Congressmen and their agents participate in this process, they are excrcising congressional and not personal rights of expression. Under such circumstances, they cannot claim protection under the First Amendment, because Congress as an institution is not shielded by that Amend. ment. T. EMERSon, THE SYSTEM OF FreedoM of Expression 700 (1970). This docs not mean that the values associated with the First Amendment-including the creation of a free marketplace of ideas and the encouragement of public comment on the ac. tivities of national leaders-are irrelevant to the constitutionality of congressional blacklisting, but rather that those values are to be considered only insofar as they are relevant to the constitutional protections that are available to Congress: the spcech and debate clause, the journal of proceedings clause, and the defense of legitimate legislative function.

It should be noted, however, that if either a Congressman or his agent should attempt to distribute or reveal the contents of a congressional blacklist on his own (without orders from a congressional body and through channels other than the Government Printing Office), he might then be able to claim the protection of the First Amendment itself for his individual expression. In that event, any attempt by the victims of the blacklist to remedy the harm imposed on them would have to deal with the recent line of cases insulating critical comment of public figures from liability for libel, except when malice is shown. See New York Times Co. v. Sullivan, 376 U.S. 254 (1964) (if the plaintiff in a libel suit is a "public official," he must prove that the defendant acted either with knowledge of the falsehood of what was written or with a reckless disregard for the truth). See also Rosenbloom v. Metromedia, Inc., 403 U.S. 29, 44.45 (1971) (the Sullivan rule applies to all libel actions dealing with utterances involving "an isstte of public or general concern'); Monitor Patriot Co. v. Roy, 401 U.S. 265 (1971); Curtis Publishing Co. v. Butts, 388 U.S. 130 (1967); Time, Inc. v. Hill, 385 U.S. 374 (1967); Rosenblatt v. Baer, 383 U.S. 75 (1966); T. EMERSON, THE SYSTEM OF Freedom of EXPRESSION 531-32, 540 (1970).

25. See, e.g., Commercial Trust Co. v. Miller, 262 U.S. 51, 57 (1923) (dictum that the judiciary may not review the determinations of the other branches as to when or whether a war has ended); New Orleans Water Works Co. v. New Orleans, 164 U.S. 471 (1896) (courts may not control the discretion of a municipal assembly to adopt or reject 
In Baker v. Carr, ${ }^{26}$ the Supreme Court attempted to provide some guidelines for the application of this general principle. Although enunciating a series of factors relevant to whether a case constituted a nonjusticiable "political question,"27 the Baker opinion indicated that the primary consideration in determining justiciability is the degree to which the constitutional provisions involved in the controversy' provide courts with enforceable judicial standards upon which to base a decision. ${ }^{28}$ In Powell $v$. McCormack, ${ }^{20}$ in holding justiciable a Congressman's claim of illegal exclusion by the House, the Court suggested that aside from the question of whether there existed a "textually demonstrable constitutional commitment of the issue"30 to Congress, all of the Baker concerns are satisfied, and the issue is therefore justiciable, if a challenged congressional activity is alleged to have infringed upon a constitutional provision that the courts are competent to interpret. ${ }^{31}$ The determination of the constitutionality of government publication is not committed exclusively to Congress. 32 Moreover, the interpretation of both provisions that a blacklist might be said to violate, the bill of attainder clause and the First Amendment, is demonstrably within the competence of courts. ${ }^{33}$ Therefore, judicial relief against congressional blacklisting would not be barred by the separation of powers doctrine. ${ }^{34}$

ordinances); Luther v. Borden, 48 U.S. (7 How.) I (1849) (Court refused to decide which of two competing groups constituted the lawful government of Rhode Island); Hearst $v$. Black, 87 F.2d 68 (D.C. Cir. 1936) (courts may not enjoin Congress from using information in its possession for the purposes of conducting hearings); Des Mloines Gas Co. $v$. Des Moines, 44 Iowa 505 (1876) (courts may not enjoin enactment of a law by a legislative body).

26. 369 U.S. 186 (1962) (holding that reapportionment of legislative districts does not present a nonjusticiable political question).

27. Id. at 217.

28. Id. at 226 .

29. 395 U.S. 486 (1969).

30. Id. at 518 .

31. Id. at 548-49.

32. See pp. 202-04 infra.

33. Courts have frequently held that threatened infringement of First Amendment rights may present a justiciable controversy despite the fact that relief would require interference with the normal functioning of a coordinate branch of government. See, e.g., United States v. Rumely, 345 U.S. 41 (1953) (separation of powers doctrine does not bar review of congressional investigations); Davis v. Ichord, 442 F.2d 1207 (D.C. Cir 1970) (the doctrine does not bar review of the maintenance of dossiers by congressional committees); Menard v. Mitchell, 430 F.2d 486 (D.C. Cir. 1970) (doctrine does not bar review of the maintenance of arrest records by the Federal Bureau of Investigation).

The bill of attainder clause is itself an implementation of the separation of posicrs principle. United States v. Brown, 381 U.S. 437,442 (1965). The claim that an act constitutes a bill of attainder must be justiciable, for otherwise Congress, under the guise of a separation of powers immunity, could violate that very system of checks and balances by usurping judicial functions. See United States v. Lovett, 328 U.S. 303, 313-14 (1916).

34. But see Doe v. McMillan, No. 71-1027, slip op. at 18.20 (D.C. Cir. Jan. 20, 1972), in which the court held that civil action against those legislative agents who helped 


\section{B. The Speech and Debate Clause}

Relief is also not barred, although it is severely limited, by the speech and debate clause, a constitutional provision designed to shield individual Congressmen from judicial interference with their official acts of expression and publication. The clause, which was copied nearly verbatim from an early English counterpart, ${ }^{35}$ states that, "The Senators and Representatives ... for any Speech or Debate in either House ... shall not be questioned in any other Place."30 Similar provisions existed in several states at the time of the Constitution's ratification. ${ }^{37}$ Indeed, the first authoritative American interpretation of this rule of government is found in Coffin $v$. Coffin, ${ }^{38}$ in which the Supreme Judicial Court of Massachusetts held that a state legislator's slanderous statement did not fall within the immunity provided by an article in the Massachusetts Constitution similar to the federal speech and debate clause. Speaking for the court, the Chief Judge stated:

I would like to define the article as securing to every member [of the legislature] exemption from prosecution, for everything said or done by him, as a representative, in the exercise of that office..... ${ }^{39}$

The United States Supreme Court has cited the Coffin formulation with approval, ${ }^{40}$ adding that the immunity only extends to statements

write and publish a congressional report alleged to infringe upon plaintiffs' right to privacy was barred, in part, by the separation of powers doctrinc. In barring rellef, however, the MCMillan court relied on two factors that distinguish the case from black: listing suits like Hentoff. In McMillan, the report had already been published when suit was brought, and plaintiffs" claim was said to be based upon "vague allegations of anticl: pated harm at some indefinable future time." Id. at 20. See also Cole v. McClellan, 439 F.2d 534, 536 (D.C. Cir. 1970). Blacklists can be enjoined before publication, and the serious. ness of the injuries suffered by the victims of blacklisting has long been recognizcd by the courts. See pp. 209-10 infra. Furthermore, McMillan was probably wrongly decided. It fails even to cite Baker or Powell on the separation of powers, and relics instead upon Methodist Federation for Social Action v. Eastland, 141 F. Supp. 729 (D.D.C. 1956), a case which has been severely undermined by more recent decisions of both the District of Columbia Circuit and the Supreme Court. Hentoff v. Ichord, 318 F. Supp. 1175, 1180 (D.D.C. 1970); Doe v. McMillan, No. 71-1027, slip op. at 36-37 (D.C. Cir. Jan. 20, 1972) (Wright, J., dissenting).

35. "That the Freedom of Speech, and Debates or Procecdings in Parliament, ought not to be impeached or questioned in any Court or Place out of Parliament." The Bill of Rights, 1689, 1 Wm. \& Mary, Sess. 2, c. 2, cited in Powell v. McCormack, 395 U.S. 486,502 n.20 (1969).

36. U.S. CoNsT, art. I, $\$ 6$.

37. Yankivich, Immunity of Congressional Speakers, 99 U. PA. L. REv, 960, 965 (1951). The Articles of Confederation also contained an analogous provision. ARTS. OF CONFED. art. $\mathrm{V}$.

38. 4 Mass. 1 (1808).

39. Id. at 27 .

40. Tenney v. Brandhove, 341 U.S. $367,373-74$ (1951); Kilbourn v. Thompson, 103 U.S. 168,203 (1881). 
made within the "power" and "role" of a Congressman."1 An activity" is said to be within the "power" of a legislator unless it is "obvious that there was a usurpation of functions exclusively vested in the Judiciary or the Executive." 12 Similarly, a Congressman is acting within his protected "role" so long as he is serving the legitimate functions of the legislature. For example, Congressmen may conduct investigations if by so doing they serve a legitimate function, such as the collection of information useful for the preparation of legislation, which is not exclusively assigned to a coordinate branch.43

Three questions arise in considering whether the speech and debate clause protects congressional blacklisting from injunction: (1) Is the publication of blacklists a legitimate congressional function? (2) If so, does the speech and debate clause protect Congressmen from injunctive relief as well as from criminal and civil sanctions for statements made in such blacklists? (3) Do the agents of Congress, acting under its authority and pursuant to its order, share the Congressmen's immunity?

\section{Blacklisting as a Congressional Function}

The blacklists under consideration are those distributed in the form of official congressional reports. ${ }^{44}$ Such reports serve at least three important legislative purposes. First, they facilitate the passage among Congressmen of information that may be useful for the preparation and evaluation of legislation. Second, they provide both the executive and judicial branches with material that might assist them in the interpretation and enforcement of resulting legislation. Third, they consti-

41. Tenney v. Brandhove, 341 U.S. $367,377-78$ (1951). There is some indication that the place in which the expression oecurs is relevant to the speech and debate protection. Thus, a speech delivered far from Capitol Hill may be more obviously divored from a legislator's official role than one recited on the floor of the Senate. However, the case law suggests that a speech or report made within the halls of Congress and othervise shielded by the speech and debate clause does not lose that protection simply because an officially printed copy of it has been distributed in places tar removed from Capitol Hill. See p. 196 and note 47 infra.

42. 341 U.S. at 378 .

43. McGrain v. Dougherty, 273 U.S. 135, 176-78 (1927).

44. The speech and debate immunity turns upon the form rather than the subject matter of the challenged expression. Thus, if preparation of congressional reports generally is covered by that clause, the authors of a particular report would not lose their immunity simply because the contents of that report are deened libelous, violative of the First Amendment, or otherwise illegal. See Kilbourn v. Thompson, 103 U.S. 163 (1881) (although Congress had no right to question petitioner concerning his business affairs or to order his incarceration for failing to answer such questions, the Congressmen involved in these activities were still held to be protected by the speech and debate clause, because the acts of conducting investigations and voting, whatever the subject matter of such acts, are within the power of Congressmen). 
tute part of the information flow to the public necessary for the evaluntion of its representatives and the legislation they produce. ${ }^{45}$ Recognizing that the effectuation of these purposes is a legitimate legislative function, the Supreme Court has stated in dictum that the speech and debate clause protects legislators for their participation in the preparation of congressional reports. ${ }^{40}$ Although lower federal courts have indicated that the immunity would not extend to the unofficial distribution of reports by individual Congressmen, ${ }^{47}$ publication by the Government Printing Office in response to a resolution of a House of Congress clearly constitutes official and therefore protected publication.

\section{Injunctive Relief}

The nature of the immunity provided by the speech and debate clause has never been fully defined. By its terms, the clause protects Congressmen from being "questioned in any other Place." Courts have long maintained that it thereby shields legislators from either criminal prosecution or civil suit for damages based upon actions falling within the immunity. ${ }^{48}$ However, a relatively novel question is posed by a suit for an injunction, since the remedy sought is arguably intended to protect the individuals affected by the disputed action, rather than to punish legislators. This issue was confronted in Stamler $v$. Willis, which involved suits to restrain the House Committee on Un-American

45. See United States v. Rumely, 345 U.S. 41, 43 (1952); E. Griffith, Concress, ITS Contemporary Role ch. 13 (1951); J. Burns, Concress on Trial ch. VI (1949); G. Galloway, Congress at the Crossronds ch. 9 (1948); W. Wilson, Congressional Gov. ERNMENT 303 (15th ed. 1900); Levi, Congressional Investigations, 18 U. Cu1. L. REV. 421 (1951).

46. Powell v. McCormack, 395 U.S. 486, 502 (1969). See also Coffin v. Coffin, 4 Mass.

1, 27 (1808); 2. T. COOLEY, Constitutional Limitations 950 (8th ed. 1927).

47. United States v. Doe, 332 F. Supp. 930, 936 (D. Mass. 1971), aff'd, 454 F.2d (lst Cir. 1972), cert. granted sub nom. Gravel v. United States, 40 U.S.L.W. 3385 (U.S. Feb. 22, 1972) (private republication of material read during a Senate subcommittec hearing is not an act protected by the speech and debate clause); Long v. $\Lambda$ nscll, 69 F.2d 386 (D.C. Cir.), aff'd, 293 U.S. 76 (1934) (the speech and debate clause docs not shield a senator from charges of libel arising out of his act of mailing excerpts of one of his Senate speeches to some of his constituents); McGovern V. Martz, $182 \mathrm{~F}$. Supp. 343 (D.D.C. 1960) (the speech and debate clause extends to the reading of statcments into the Congressional Record but not to the private distribution of copies of the Record, the former act being an "official" legislative function and thercfore protected, the latter an "unofficial" act and therefore vulnerable). Congressmen who lose the pro. tection of the speech and debate clause because they have engaged in unofficial acts of publication may, for that very reason, be able to claim at lcast the partial immunity provided by the First Amendment. See note 24 supra.

48. Tenney v. Brandhove, 341 U.S. 367,787 (1951); Kilbourn v. Thompson, 103 U.S. 168, 203 (1881). Cf: United States v. Johnson, 383 U.S. 169 (1966). See also L. Cusiling, Law and Practice of Legislative Assemblies $\$ 601$ (2d ed. 1866).

49. 287 F. Supp. 734 (N.D. Ill.), appeal dismissed, 393 U.S. 217, remanded, 393 U.S. 407 (1968), subsequent decision appealed, 415 F.2d 1365 (7th Cir. 1969), cert. denied sub nom. Ichord v. Stamler, 399 U.S. 29 (1970). 
Activities from conducting any hearings and taking any action to enforce subpoenas served on plaintiffs, and to enjoin both the operation of the House rule establishing the Committee and future prosecutions for contempt of Congress. Two judges of the three-judge district court ruled that the speech and debate clause, when applicable, forbids injunctive relief as absolutely as it forbids criminal and civil sanctions. The court stated that any judicial interference with legislative debate would constitute a proscribed "questioning" of Congressmen, so that if congressional expression "impinges upon another's First Amendment rights, the former must prevail." "50 This opinion fostered a vigorous dissent, which declared that "the [speech and debate] immunity does not extend to actions for declaratory and injunctive relief in which, as here, Congressmen are only parties in their official capacity." 51 This issue has not been decided by an appellate court: Stamler was remanded on other grounds ${ }^{52}$ and the Supreme Court, in Powell v. McCormack, ${ }^{53}$ explicitly reserved judgment on the question..$^{54}$

An examination of the actual effects of an injunction suit suggests that the original Stamler holding was correct. The Powell Court stated:

The purpose of the protection afforded legislators [by the speech and debate clause] is not to forestall judicial review of legislative action but to insure that legislators are not distracted from or hindered in the performance of their legislative tasks by being called into court to defend their actions. ... Freedom of legislative activity and the purposes of the Speech and Debate Clause are fully protected if legislators are relieved of the burden of defending themselves. .55

A suit for injunctive relief imposes some of the same interferences with legislative tasks as do other court actions. If a legislator against whom

50. Stamler v. Willis, 287 F. Supp. 734, 739 (N.D. Ill. 1968).

51. Id. at 741 (Cummings, J., dissenting).

52. The Supreme Court, 393 U.S. 407 (1968), remanded for entry of a fresh decree by a single-judge district court, which then dismissed the complaints against all defendants under the speech and debate clause. On appeal, the Seventh Circuit remanded the case as to the non-Congressmen for reconsideration in light of Powell. Although it affirmed the dismissal as to the congressional defendants, it did so, like Powell, only because relief against the others would provide an adequate remedy and specifically reserved judgment on the question of whether or not the speech and debate clause bars injunctive relief. 415 F.2d 1365, 1368 (7th Cir. 1969). No subsequent opinion in that controversy is reported.

53. 395 U.S. $486(1969)$.
54. Id. at 506 n.26. The commentators are divided on this issuc. Compare Comment, Power to Enjoin Publication by Congress of Libelous Maller, 43 IowA L. REv. 132, 135.37 (1957), with Comment, Court Refuses to Enjoin Publication by Congress of Pamphlet Containing Defamatory Material, 70 HARv. L. REv. 723, 720 (1957).

55. Powell v. McCormack, 395 U.S. 486, 505 (1969). 
an injunction is sought chooses to contest the suit, he will be forced to expend essentially the same amount of time, effort and money in the development and presentation of a defense as he would had the relief sought been money damages or a prison term. If, on the other hand, he chooses to disregard the suit and the resulting injunction, he might be subject to a proceeding for contempt, which would have the same disruptive effects as criminal prosecutions, which are clearly banned by the speech and debate clause. Since suits for injunctive relief pose the very danger to the freedom of legislative activity that the clause was designed to circumvent, ${ }^{56}$ it would seem that the clause must be interpreted to protect Congressmen from defending their official acts of expression and publication in such proceedings.

\section{Congressional Agents}

This conclusion does not compel a further finding that the agents of Congress are similarly immune from injunction for their roles in publishing a congressional blacklist. On the contrary, the case law indicates that they will normally not be protected by the immunity of their principals. Since the purpose of the speech and debate clause is to protect Congressmen and not their expression per se, the decisive question would seem to be whether court action against an agent of Congress would interfere with a Congressman's performance of his legislative duties.

Although the early cases agreed that the speech and debate clause does not protect agents of Congress to the same extent that it shields the legislators themselves, there was some ambiguity as to whether it offered agents any protection. ${ }^{57}$ Powell v. McCormack ${ }^{58}$ indicated that the speech and debate clause offers no protection to congressional

56. See THE Works of JAMEs WiLson 421 (R. McCloskey ed. 1967), cited with approvial in Powell v. McCormack, 395 U.S. 486, 503 (1969), for a useful description of the rolc of the speech and debate clause: "In order to enable and encourage a representative of the publick to discharge his publick trust with firmness and success, it is indispensably necessary, that he should be protected from the resentment of every one, howcver powerful, to whom the exercise of that liberty might occasion offense." See also United States v. Johnson, 383 U.S. 169, 181 (1966), in which it is stated that the purpose of the speech and debate clause is "to prevent intimidation [of legislators] by the executive and accountability before a possibly hostile judiciary."

It should be noted that an injunction itself, as compared with a suit for an injunction, causes at least as much, if not more, interference with the legislative powers since it bans outright what a damage judgment or prison term would only seek to remedy after the fact.

57. Compare Kilbourn v. Thompson, 103 U.S. 168 (1881) (dictum that specch and debate clause provides no protection for congressional agents), with Dombrowski $v$. Eastland, 387 U.S. 82, 85 (1967) and Tenney v. Brandhove, 341 U.S. 367, 378 (1951) (dictum that speech and debate clause, although applicable to congressional agents, provides them with a less absolute immunity).

58. 395 U.S. 486 (1969). 
agents who participate in unconstitutional or otherwise illegal activities. In holding that both declaratory and injunctive relief were available against congressional agents in order to redress the wrongful denial of a congressional seat and its attendant privileges to Representative Adam Clayton Powell, the Court stated that "legislative employees who participated in unconstitutional activity are responsible for their acts" and are not shielded from judicial intervention by the speech and debate clause. ${ }^{59}$

Despite this broad ruling in Powell, two recent circuit court decisions have attempted to extend the speech and debate immunity to some congressional agents. In United States $v . D o e^{00}$ the First Circuit held that a Senator's personal legislative aides are immune from grand jury interrogation concerning the Senator's legislative activities. This ruling can be distinguished from blacklisting cases on at least two separate grounds. First, the Doe court accorded protection to legislative aides because they enjoyed such a confidential relationship with their respective Congressmen that harassment of an aide would amount to harassment of the legislator himself, which the speech and debate clause was designed to prevent. ${ }^{61}$ The agents involved in publishing congressional reports (the Public Printer, the Superintendent of Documents, and their subordinates) do not maintain such intimate working relationships with the Congressmen who draft those reports. Second, the Doe case involved a grand jury investigation, while suits to enjoin blacklists (like the suit in Powell) are civil in nature. This distinction is significant because grand jury investigations are initiated and directed by the executive branch, and therefore present a far greater potential for coordinated and persistent harassment of legislators by an

59. Id. at 504. See also Dombrowski v. Eastland, 387 U.S. 82 (1967), in which the Court ruled that the Chief Counsel to the Senate Internal Security Subcommittee was not shielded by the absolute immunity of the specch and debate clause in an action alleging violation of the plaintiff's Fourth Amendment rights.

60. 454 F.2d - (1st Cir. 1972), cert. granted sub nom. Gravel v. United States, 40 U.S.L.W. 3385 (U.S. Feb. 22, 1972). The court held that the grand jury could not compel Dr. Leonard Rodberg or any of Senator Gravel's other aides to testity concerning the Senator's legislative activities during the time of their employment by Gravel. Hovicver, other congressional agents and third parties were held to be immune only to questions concerning their communications with the Senator or his aides directed to the Senator's motives in carrying out his legislative activities.

61. In Ansara v. Eastland, 442 F.2d 751 (D.C. Cir. 1971), the District of Columbia Circuit relied on a similar theory in refusing to enjoin a Senate Subcommitce or its agents from subpoenaing plaintiffs and certain documents in their possession. Although not mentioning the speech and debate clause, the court held that judicial intervention was inappropriate when it might create "needless friction" by halting "the ongoing Iegislative process." Id. at 753. The court explicitly distinguished Hentoff on the ground that publication only occurs after all opportunities for "legislative determination as to the matter in controversy" are past and is thus not part of the protected legislative process. Id. at 753 n.3. 
equal branch of government than do suits for injunction brought by private individuals. ${ }^{62}$

In Doe v. McMillan, ${ }^{63}$ the District of Columbia Circuit adopted a broad interpretation of the scope of the speech and debate clause in denying relief against certain legislative and executive officials who had helped to prepare and publish a congressional report alleged to infringe upon plaintiffs' right to privacy. The court did not limit its holding to those agents intimately involved in the legislative process, but instead ruled that "when congressional employees or officers arc acting pursuant to valid legislative authorization, in furtherance of a proper legislative purpose, they also come within the scope of the Speech or Debate Clause protection." 65 The authorities cited do not

62. United States v. Doc, 332 F. Stup. 931, 935 (D. Mass. 1971), aff'd, 454 Fi.2d (1st Cir. 1972), cert. granted sub nom. Gravel v. United States, 40 U.S.L.W. 3985 (U.S. Feb. 22, 1972). Cf. United States v. Johnson, 383 U.S. 169, 181 (1966), in which the Court lists "intimidation by the executive" as one of the major dangers which the specch and debate clause was designed to prevent.

63. No. 71-1027 (D.C. Cir. Jan. 20, 1972).

64. See note 61 supra.

65. Doe v. McMillan, No. 71-1027, slip op. at 17 (D.C. Cir. Jan. 20, 1972). The court actually denied relief on three separate grounds, none of which seems to support the decision. It held that all of the named defendants were immune from suit under the speech and debate clause, the separation of powers doctrinc, and the doctrine of of. fícial immunity.

This last doctrine is a judicially created immunity that protects government agents from certain suits arising out of acts done in the course of their official duties, Barr $v_{\text {. }}$ Matteo, 360 U.S. 564, 569.71 (1959); Gregoire v. Biddle, 177 F.2d 579, 581 (2d Cir. 1949). Although the immunity is absolute when applicable, the limits of its scope have not been clearly defined. It is firmly established that this common law protection is available only to officials under attack for their performance of discretionary rather than ministerial duties. David v. Cohen, 407 F.2d 1268, 1272 (D.C. Cir. 1969). This distinction is dictated by the doctrine's primary purpose, which is to free the exercise of judgment by government agents from the inhibiting threat of court action by those whom their decisions affect. The doctrine also appears to be limited to tort actions in which an official is sued for monetary damages, since the immunity was designed not to shicle government officials from all judicial inquiry but only to relieve them of the inhibiting fear that their official acts would render them personally liable for damage judgments. See, e.g., Carter v. Carlson, 447 F.2d 358, 362-63 (D.C. Cir. 1971), cert. granted sub nom. District of Columbia v. Carter, 92 S.Ct. 683 (1972). A third limitation upon the scope of official immunity has been suggested but not settled: the doctrine may be inapplicable to agents of the legislative branch. See Note, The Scope of Immunity for Legislators and Their Employees, 77 YALE L.J. 366, 373.75 (1967). The speech and debate clatise is a constitutional shield offering legislators and perhaps some of their agents as well a criminal and civil immunity far broader than any enjoyed by officials of the other two branches. It can be argued that this provision was meant to preempt the ficld of legislative immunity, and that the relatively recent common law doctrine of official immunity was merely intended to provide some similar safeguards to the constitutionally unprotected agents of the executive and judicial branches. This interpretation is stip. ported by dictum in Barr v. Matteo, 360 U.S. 564, $569-70$ (1959), which suggests that the speech and debate clause is the legislative counterpart of executive and judicial immunity, and by the fact that the major cases on the liability of legislative agents fail even to discuss the possibility of a common law bar to justiciability. See, e.t., Powell v. McCormack, 395 U.S. 486 (1969); Dombrowski v. Eastland, 387 U.S. 82 (1967). The Supreme Court has only once been asked to decide whether or not congressional agents enjoy a common law immunity from suit, and it sidestepped the isste by holding that the actions in question were outside the scope of the agent's delegated authority and 
support this broad conclusion. Just before announcing its holding, the McMillan court cites Dombrowski v. Eastland ${ }^{00}$ and Tenney v. Brandhove. ${ }^{67}$ Yet, as the quotation used by the court indicates, those cases speak only of a limited immunity for legislative agents. ${ }^{68}$ Similarly, the First Circuit decision in United States v. Doe, which McMillan cites as direct support for its ruling, applies the clause only to a very limited class of agents who enjoy a personal relationship of close confidence with a Congressman. Furthermore, MICMillan distinguishes Kilbourn v. Thompson ${ }^{69}$ and Powell, the two Supreme Court cases that appear to reject agent immunity altogether, on the ground that they dealt with actions by agents in response to invalid authorization, while the House District Committee's enabling resolution in the McMillan controversy was termed "clearly valid."70 This reasoning assumes the very issue to be decided. If the House District Committee's order to publish the challenged report unjustifiably infringed upon plaintiffs' right to privacy, it was as "invalid" as Congress" decision to divest Adam Clayton Powell of his seat. McMillan was, therefore, decided wrongly, as Judge J. Skelly Wright maintains in his vigorous dissent. ${ }^{71}$ If the speech and debate clause offers any immunity to the agents of Congress, it is probably limited to situations like that described in Doe, in which certain agents are so intimately involved with the work of Congressmen that judicial action against those agents would interfere with and intim-

thus ineligible for the official immunity shield on that narrower ground. Whecldin $\mathbf{Y}$. Wheeler, 373 U.S. 647, 651 (1963).

In view of these restrictions, the McMillan court was probably not justified in dis. missing plaintiffs' request for injunctive relief against the agents of the Goverrment Printing Office on the basis of a common law immunity. Those agents were cmplojees of the legislative branch, an injunction does not entail financial liability, and the activity that plaintiffs sought to enjoin-the publication of a House report-was a ministerial task involving no discretionary policy decisions. For precisely the same three reasons, injunctive relief against the publication of a congressional blacklist could not be barred by the doctrine of official immunity.

The Supreme Court will soon have the opportunity to clarify some of the ambiguity which surrounds this doctrine. In United States v. Doe, 454 F.2d - (1st Cir. 1972), ceri. granted sub nom. Gravel v. United States, 40 U.S.L.W. 3385 (U.S. Fcb. 22, 1972), the First Circuit relied primarily upon the speech and debate clause to shicld Senator Gravel and his aides from grand jury interrogation, but it suggested that under certain circumstances, those officials might enjoy a common law immunity as well. The Supreme Court has specifically included the issue of official immunity for legislative agents among the questions it will consider in its review of Doe. 40 U.S.L.W. at 3385 . However, cien if the Court should decide that the doctrine applies to employees of the legislative branch threatened by grand jury questioning concerning their official duties, thereb) greatly expanding that immunity, the ministerial task of printing blacklists should still be beyond its scope.

66. 387 U.S. 82 (1967).

67. 341 U.S. 367 (1951).

68. See note 57 supra.

69. 103 U.S. 168 (1881).

70. Doe v. McMillan, No. 71-1027, slip op. at 17 n.17 (D.C. Cir. Jan. 20, 1972).

71. Id. at $29-47$. 
idate the Congressmen themselves. Such an immunity would seem not to extend to members of the Government Printing Office involved solely in the physical reproduction of a document after completion of all legislative deliberation as to its contents. ${ }^{72}$

\section{The Journal of Proceedings Clause}

Another possible restriction on judicial interference with legislative publication, which was not raised by the defendants in Hentoff and McMillan, is the constitutional mandate that "Each House shall keep a Journal of its Proceedings, and from time to time publish the same, excepting such Parts as may in their Judgment require Secrecy." 73 Given this affirmative obligation to publish a record of congressional operations and its apparent policy of insuring public knowledge about the legislature's activities, ${ }^{74}$ it could be argued that the judiciary is powerless to interfere with the publication and dissemination of any congressional document.

This argument, however, sweeps too broadly. First, a congressional report is probably not a "Journal of ... Proceedings" within the meaning of this clause. Unlike the Congressional Record or a transcript of a committee hearing, ${ }^{\tau \tau}$ a report is not a record of a congressional "proceeding" but rather a statement of findings of fact, opinions, and recommendations. ${ }^{76}$ More importantly, reports are normally drafted by committees and subcommittees, while the journal clause is generally considered applicable only to records of the proceedings of each House meeting as a whole. ${ }^{77}$ In fact, the Court has specifically stated that each House may at its discretion decide whether or not to place the full text

72. Although these officials would be protected by neither the specch and debate clause nor the First Amendment, see note 24 supra, for their acts as agents of Congress, they might still be immune from suit for damages to the extent that any of their decisions are discretionary in nature, under the doctrine of official immunity. See note 65 supra.

73. U.S. CoNSr. art. I, $\S 5$, cl. 3.

74. See Field v. Clark, 143 U.S. 649, 670-71 (1892), quoting 1 J. Story, Commentak1es oN THE Constitution of THE UNited STates $\$ \$ 840,841$ (1873), to the effect that the purpose of that clause is "to ensure publicity to proceedings of the legislature, and a correspondent responsibility of the members to their respective constituents." See also Hennings, The People's Right to Know, 45 A.B.A.J. 667, 669 (1959).

75. See Note, $A$ Defendant's Right to Inspect Pretrial Congressional Testimony of Government Witnesses, 80 YALE L.J. 1388, 1406 (1971).

76. See T. Norton, The Constitution of THE United States, Its Sources and Its Application 28 (1966), in which the author implies that the printing of "cvery word uttered in the House and in the Senate" satisfies the requirement of the journal clausc.

77. Corwin states that even the proceedings of a House meeting as a whole need not fall within the journal clause if it meets as a "committee of the whole" rather than as a normal plenary session. E. CoRwin, The Constitution and Wiat It MEans Todar 18 (1963). But see Note, supra note 75, at 1406. 
of a report into its required journal of proceedings, ${ }^{78}$ which implies both that reports published separately do not themselves constitute such journals and that the publication of all reports is not deemed necessary to effectuate the purposes of the journal clause.

Furthermore, the provision's primary purpose of insuring public knowledge would seem fully satisfied by the preservation of one complete record of congressional activities. As long as publication of the Congressional Record is protected and Congressmen have access to the Record for the purpose of including material other than floor debates, ${ }^{79}$ the constitutional purpose will be fully achieved even if other forms of publication are enjoined. ${ }^{80}$ It is not surprising, therefore, that every case which has dealt with the journal clause has done so solely in the context of the Congressional Record, ${ }^{81}$ and that the commentators have assumed that publication of the Record satisfies the mandate of that provision. ${ }^{82}$

Second, it does not follow from the fact that Congress has a duty to publish a journal that its power to do so is never subject to limitation. All powers granted to Congress by Article I of the Constitution are subject to the limitations imposed by the First Amendment and other restrictive provisions. The power to publish is no different because of its apparently mandatory nature ("Each House shall keep a Journal") -the First Amendment, after all, is also obligatory: "Congress shall

\section{Field v. Clark, 143 U.S. 649, 671 (1892):}

[I]t is clear that, in respect to the particular mode in which, or will what fulness, shall be kept the proceedings of either house relating to matters not expressly required to be entered on the journals; whether bills, orders, resolutions, reports and amendments shall be entered at large on the joumal, or only referred to and desig. nated by their titles or by numbers; these and like matters were left to the discretion of the respective houses of Congress (emphasis added).

79. A Congressman has the right, subject to the unanimous consent of his House. to place materials, including congressional reports, into the Congressional Record. See

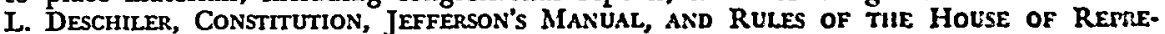
Sentatives \& 929 (1971); L. Schameckebier \& R. Eastin, Governasent Publications and THEIR UsE $140-44$ (2d ed. 1969).

80. Hentoff v. Ichord, 318 F. Supp. 1175, $1180-81$ (D.D.C. 1970). The court coneluded that the independent publication of a House report was not required by the journal of proceedings clause.

81. United States v. Ballin, 144 U.S. I (1892); Ficld v. Clark, 143 U.S. 619 (1892): Provost v. Morgenthau, 106 F.2d 330, 335 (D.C. Cir. 1939). Other cases which mentioned the clause in passing did not attempt to define the nature of the "Journal of Proceedings." Wright v. United States, 302 U.S. 583, 588 (1938); Flint v. Stone Trac' Co., 220 U.S. 107, 143 (1913).

Actually, the journal clause technically applies only to the official Journals of both Houses, which together contain the daily proccedings in Congress and which, subject to amendment, are printed as the main sections of the Congressional Record. Sce I. Deschiler, Constitution, JefFerson's MAanual, ANd Rules of tile House of REphesentaTIVES 26 (1969).

82. See T. Norton, supra note 76, at 28; I B. Schwartz, A Cossuentari os the Constitution OF the UNITED States 108 (1963). 
make no law ...."83 Moreover, the power to publish a journal is in fact somewhat discretionary. The journal clause explicitly authorizes ench House to exclude any information deemed to require secrecy (an allthority which, though normally used to cloak matters of national sccurity, was recently used to protect an individual's constitutional rights $\left.{ }^{84}\right)$, and the Court has stated that the inclusion of materials other than plenary proceedings (such as reports) is left to the discretion of Congress. ${ }^{85}$ Finally, the journal is not protected from judicial interference simply because the journal clause assigns decisions regarding its contents to the judgment of the relevant House of Congress. The Court has held that the rules of each House ${ }^{80}$ and the qualifications of its membership, ${ }^{87}$ two other issues as to which Article I, Section 5 explicitly calls for congressional judgment, are nonetheless subject to judicial scrutiny when they affect individual rights.

Even if, as seems probable, congressional reports do not form part of the mandated "journal of proceedings," the power of courts to enjoin publication of that journal would become a critical issue should a committee or an individual Congressman seek to circumvent an injunction against the publication of a report by placing the text of that report into the Congressional Record. ${ }^{88}$ As noted above, the journal clause does not per se prohibit judicial action against the Congressional Record, and the purpose of that provision-to prevent the legislature from holding secret proceedings-would not seem thwarted by an occasional judicial excision from the Record of materials whose publication is discretionary, ${ }^{80}$ when publication would seriously jeopardize individual rights. 90

\section{The Constitutionality of Congressional Blacklisting}

The analysis thus far indicates that the general agents of Congress can be enjoined from publishing a congressional report, either sep-

83. U.S. Covsr, amend. I (emphasis added).

84. See Note, supra note 75 , at 1406. A House subcommittec investigating the My Lai incident decided to keep secret testimony given during the inquiry on the ground that its public release might prejudice the partics in upcoming criminal cases.

85. See note 78 supra.

86. United States v. Smith, 286 U.S. 6, 33 (1932); United States v. Ballin, 144 U.S. 1, 5 (1892).

87. Powell v. McCormack, 395 U.S. 486 (1969).

88. The Record probably enjoys at least as large a circulation as do rcports printcd separately by the Government Printing Office.

89. See note 78 supra.

90. But see Hentoff v. Ichord, 318 F. Supp. 1175, 1179, 1180 (D.D.C. 1970). Although plaintiffs explicitly did not request such relief, the Hentoff court stated in dicta that the Congressional Record could not be enjoined, and seemed to base that conclusion upon both the journal of proceedings and the speech and debate clauses. 
arately or possibly even in the Congressional Record, if such publication were found to violate the Constitution. It is thus necessary to confront the second and potentially more important question posed by the Hentoff case: Is the publication of a congressional blacklist an unconstitutional act? Two separate lines of attack will be examined: first, that a congressional blacklist constitutes a bill of attainder; and second, that it constitutes a violation of the blacklist victims' First Amendment freedoms of expression and association.

\section{A. The Bill of Attainder Claim}

The constitutional bar against bills of attainder ${ }^{01}$ is based upon two old English counterparts, which prohibited extrajudicial trial and punishment at the hands of Parliament. ${ }^{92}$ Its basic purpose is to maintain the separation of governmental powers by preventing usurpation of the judicial function through individualized, deprivational classifications made by legislatures..$^{93}$ The classic bill of attainder may be described as a legislative enactment naming an individual, reciting certain "crimes" committed by him (for which no judicial proceedings had been initiated), declaring him to be guilty of those crimes, and ordering that he be punished through the deprivation of life, liberty or property. ${ }^{94}$ Although the bill of attainder clause has rarely been used by the Supreme Court to invalidate a law, ${ }^{05}$ the decisions and

91. The Constitution actually contains two provisions prohibiting bills of attainder: one addressing itself to Congress, U.S. CoNst. art. I, $\$ 9, \mathrm{cl}$. 3; and the other to the state legislatures, U.S. Consr. art. I, § 10, cl. 1. Since the cases do not stress this distinction and seem to assume that both provisions should be interpreted identically, the term "bill of attainder clause" will be used in this Note to refer to both provisions, although it should be understood that congressional blacklisting is subject to attack only under the prohibition in Section 9.

92. The American bill of attainder clause actually had its origin in two separate English legal forms: the Bill of Attainder and the Bill of Pains and Penalties. The former was used only to inflict the death sentence; the latter for lesser penalties. In both cases, the term was applied to parliamentary trial and punishment of specified individuals without recourse to formal judicial proceedings or the attendant rights of the accused. Note, The Bill of Attainder Clause and Legislative and Administrative Suppression of "Subversives," 67 CoLuM. L. REv. 1490, 1492 (1967).

93. Note, The Bounds of Legislative Specification: A Suggested Approach to the Bill of Attainder Clause, 72 YaLE L.J. 330, 333 (1962).

94. For a similar model, see Note, supra note 92 , at 1491 .

95. United States v. Brown, 381 US. 437 (1965) (a federal law making it a crime for anyone who was or had been during the prior five years a member of the Communist Party to accept an office or employment in a labor union); United States v. Lorct, 328 U.S. 303 (1946) (a federal statute barring payment of salarics to three named government employees suspected of subversion); Pierce v. Carskiadon, 83 U.S. (16 Wall.) 234 (1872) (a West Virginia statute allowing civil judgment and attachment without cither personal service upon or personal appearance by the adierse party); Ex parte Garland, 71 U.S. (4 Wall.) 393 (1866) (a federal statute providing that no one shall be admitted to the bar of the United States Supreme Court without swearing that he has neter supported an authority hostile to the United States government); Cummings v. Mliceouri, 71 U.S. (4 Wall.) 277 (1866) (a state constitutional amendment requiring clergy to take an oath that they had never committed acts in support of the Confederacy). 
dicta of the Supreme Court as well as the clause's essential purpose indicate that it applies to a much broader group of congressional acts than are encompassed by this narrow, classic model of attainder. ${ }^{00}$

\section{The Dimensions of the Bill of Attainder Prohibition}

First, although all three congressional acts that have thus far been voided under the bill of attainder clause were statutes, ${ }^{97}$ the provision should also be read to encompass other products of the legislative process preparatory or ancillary to the enactment of laws. The bill of attainder cases speak in terms of "legislative acts" rather than specifically limiting the scope of the clause to statutes, ${ }^{08}$ and the Court has repeatedly stressed the importance of effect over form:

[T] he Bill of Attainder Clause was intended not as a narrow, technical (and therefore soon to be outmoded) prohibition, but rather as an implementation of the separation of powers, a general safeguard against legislative exercise of the judicial function, or more simply - trial by legislature. ${ }^{99}$

Since a congressional report can produce as much harm as a statutory enactment, ${ }^{100}$ and since both can usurp the judicial function by condemning individuals on the basis of a legislative finding rather than a court judgment, a congressional report should be considered a "legislative act" subject to the bill of attainder prohibition. ${ }^{101}$

The fact that reports are technically the products of committee ac-

96. But see United States v. Lovett, 328 U.S. 303, 321-24 (1946) (Frankfurter, J., con* curring). Justice Frankfurter suggested that a bill of attainder must include (1) specific naming, (2) a listing of bad acts, (3) a recital of guilt, and (4) the deprivation of a vested right which cannot be avoided by a change of conduct on the part of those so named. Frankfurter's definition, however, has never been accepted by the Court.

97. United States v. Brown, 381 U.S. 437 (1965); United States v. Lovett, 328 U.S. 303 (1946); Ex parte Garland, 71 U.S. (4 Wall.) 333 (1866). The Court has also invalidated two state enactments: a statute, Pierce v. Carskadon, 83 U.S. (16 Wall.) 234 (1872) and a state constitutional amendment, Cummings v. Missouri, 71 U.S. (4 Wall.) 277 (1866). See note 95 supra.

98. See, e.g., United States v. Lovett, 328 U.S. 303, 315 (1946); Cummings v. Missouri, 71 U.S. (4 Wall.) 277, 323 (1866). In fact, the act invalidated in Cummings was a constitutional amendment, not a statute.

99. United States v. Brown, 381 U.S. 437, 442 (1965). See also p. 208 infrat.

100. See pp. 209.10 infra.

101. James Madison apparently believed that the bill of attainder prohibition applicd to anything entailing a congressional vote. In November of 1794, he opposed a resolution introduced in Congress, which expressed public disapproval of certain "self-created Democratic societies," on the ground that "[i]t is vain to say that this incliscriminaut censure is no punishment. If it falls on classes, or individuals, it will be a severe punish. ment. . . Is not this proposition, if voted, a vote of attainder?" 4 . AN.vills of Coxi. 934 (1794), cited in Joint Anti-Fascist Refugee Committec v. McGrath, 341 U.S. 123, 144 n.l (1951) (Black, J., concurring). 
tion rather than acts of the legislature as a whole should not bar relief. First, a committee is a creature of Congress, having no independent constitutional existence and owing all of its authority to the delegated legislative power of Congress as a whole. H.R. 91-1732, for instance, was prepared pursuant to explicit statutory authorization empowering the House Internal Security Committee to investigate subversive activities and to report about them. ${ }^{102}$ It seems inconceivable that Congress could grant its constituent bodies a power to attaint individuals which Congress itself lacks. ${ }^{103}$ Indeed, two Supreme Court Justices have concluded that even certain acts of administrative bodies constitute bills of attainder, ${ }^{104}$ despite the fact that courts have held valid the delegation of quasi-judicial functions to administrative agencies. ${ }^{105}$ Second, although reports are usually written by committees or subcommittees, they can only be published upon order of either House, and the power to publish is itself delegated to the individual Houses by an Act of Congress. ${ }^{100}$ This process is not significantly distinguishable from the enactment of statutes, which are often written substantially in committee and formally approved by both Houses. Thus, neither the nature of the act nor its source would preclude application of the bill of attainder prohibition to congressional reports.

The classic model's requirement of specificity is also narrower than existing law, for a bill of attainder need not actually name the persons to be punished. Although frequently used to punish specifically named individuals, the early English acts of attainder occasionally inflicted harm on large groups of people, designating them only by the name of their organization or simply by general description. ${ }^{107}$ The Supreme Court adopted this broad approach in three post-Civil War cases, in which punishment was inflicted on citizens described only as parties to a civil suit or as men unwilling to swear that they had not been

102. Legislative Reorganization Act of 1946, ch. 753, tit. I, 60 Stat. 828 (1910). This authorization, which originally applied to the House Committec on Un-Ameriean Activities, has been made applicable to that committec's successor, the House Internal Security Committee. See note 6 supra.

103. Note, supra note 92, at 1500-02.

104. See Peters v. Hobby, 349 U.S. 331, 352 (1955) (Douglas, J., concurring) (decision of Civil Service Commission's Loyalty Review Board to bar petitioner from federal service for three years upon an administrative finding of doubiful loyalty violates the bill of attainder clause); Barsky v. Board of Regents, 347 U.S. 442,460 (1951) (Black. J., dissenting); Joint Anti-Fascist Refugee Commitice v. MIcGrath, 341 U.S. 123, 144 (1951) (Black, J., concurring). In the last two opinions, Justice Black concluded that the Attorncy General's list of subversive organizations violated the bill of attainder clause.

105. See K. Davis, Administrative Law $\S 18$ (1951).

106. 44 U.S.C. § 701 (1970).

107. See acts cited in United States v. Brown, 381 U.S. 437, 461 n.37 (1965). 
loyal to the Confederacy. ${ }^{108}$ In a more recent case, the Court stated that

legislative acts, no matter what their form, that apply either to named individuals or to easily ascertainable members of a group in such a way as to inflict punishment on them without a judicial trial are bills of attainder prohibited by the Constitution. ${ }^{109}$

That this broad statement should have been made in an attainder case in which the challenged act actually specified its victims by name $\mathrm{e}^{110}$ indicates the Court's awareness that the clause was designed to prevent subtle as well as direct legislative specification.

The classic requirements of formality in punishment-a listing of bad acts and a recital of guilt-have also been relaxed. In two of the Civil War cases, the Court explicitly held that a recital of guilt is not a necessary element of bills of attainder, ${ }^{111}$ and the statute voided in United States $v$. Brown ${ }^{112}$ did not list any bad acts that all members of the Communist Party had committed.

The cases also have outlined a much broader concept of the punishment needed to establish a bill of attainder than the classic model suggests. As early as 1866, the Court, in Cummings v. Missouri, ${ }^{113}$ stated that " $[t]$ he deprivation of any rights, civil or political, previously enjoyed, may be punishment, the circumstances attending and the causes of the deprivation determining this fact."114 As that decision explained, this broad definition of harm encompasses intangible as well as material deprivations:

We do not agree with the counsel of Missouri that 'to punish one is to deprive him of life, liberty, or property, and that to take anything less than these is no punishment at all.' The learned counsel does not use these terms-life, liberty, and property-as comprehending every right known to the law. He does not include under liberty freedom from outrage on the feelings as well as restraints on the person. He does not include under property those estates

108. Pierce v. Carskadon, 83 U.S. (16 Wall.) 234 (1872); Ex parte Garland, 71 U.S. (4 Wall.) 333 (1866); Cummings v. Missouri, 71 U.S. (4 Wall.) 277 (1866).

109. United States v. Lovett, 328 U.S. 303, 315-16 (1946) (emphasis addcd).

110. See note 95 supra.

111. Ex parte Garland, 71 U.S. (4 Wall.) 333 (1866); Cummings v. Missouri, 71 U.S. (4 Wall.) 277 (1866).

112. 381 U.S. 437 (1965).

113. 71 U.S. (4 Wall.) 277 (1866).

114. Id. at 320 . The actual "punishment" inflicted by the law under review in Cummings consisted in a limitation of the types of employment available to those un willing to take the required loyalty oath. 
which one may acquire in professions, though they are often the sources of the highest emoluments and honors. ${ }^{115}$

There can be little doubt that blacklisting of the type exhibited by H.R. 91-1732 can cause irreparable injury to its victims, including damage to person and property as well as to the intangibles of reputation and esteem described in Cummings. This injury can take essentially three forms: deprivation, personal intimidation, and intimidation of those whom the blacklist victim hopes to recruit to his group or cause.

The deprivational threat inherent in blacklisting derives from the likelihood of public reaction against those whom the government officially brands with unpopular labels. The danger of private sanctions against individuals exposed as non-conformists was recognized by de Tocqueville more than a century ago, ${ }^{110}$ but the full power of collective intolerance has been revealed only recently with the advent of effective mass communications. ${ }^{117}$ Such private sanctions can be as harmful as judicial punishment; as one commentary notes, "[l]oss of a job ... may entail greater economic deprivation than a fine. And isolation within society (ostracism) is not wholly unlike isolation from society (imprisonment)."118

Unjustified disclosure of damaging information has also been condemned because of its "chilling effect" on the future exercise of First

115. Id.

116. A. DE Toceueville, Democrscy in AMerica 264 (P. Bradley ed. 1957). As perceptive as de Tocqueville was, he seems to have overlooked two aspects of this problem rhich are of particular importance to an examination of blacklisting. First, although de Tocqueville's democratic "master" allows the dissenter to retain his life and property', the McCarthy era revealed that those who wield public and private influence might not be so kind. See note 118 infra. Second, it should be noted that his "master" is actually" a personification of the American "majority." That characterization is incomplete, how: ever, without mention of the role that a relatively small number of influential people may play in shaping and focusing the opinions of that majority. A blacklist exhibiting what appears to be official government endorsement would carry with it enhanced authority as it both interacted with and shaped public opinion. The danger presented by official condemnation of private individuals is emphasized in Finman \& Macaulay, Free. dom to Dissent: The Vietnam Protests and the Words of Public Officials, 1966 Wis. $X$. REv. 632, 679.

11\%. The effect of government condemnation in today's world of instantancous nationwide communications is illustrated by the following incident. On March 5, 1966, newspapers carried the story that the United States Attorney General had decided to institute legal proceedings to force the W.E.B. Du Bois Club to register as a communist organization. Within twenty-four hours, club members were beaten in Brooklyn and the club's San Francisco headquarters was bombed. Finman \& Macaulay, supra note 116, at 633 , citing N.Y. Times, March 5, 1966, $\$ 1,3 t 1$, cols. 6-7 and 4, cols. 3.5; N.Y. Times, March 6, 1966, § 2, at 53, col. 1 .

118. Finman \& Macaulay, supra note 116, at 694. See also Joint Anti-Fascist Refugce Comm. v. McGrath, 341 US. 123, 142 (1951) (Black, J., concurring); Note, supra note 92, at 1506-08. 
Amendment freedoms. ${ }^{110}$ This effect is manifested in two separatc ways. The victims of such disclosure may be reluctant to maintain those affiliations or repeat those statements that led to their exposure and public condemnation. Furthermore, those who are willing to continue to exercise their rights may find themselves unable to gain recruits for their cause, because government exposure has frightened away many who might otherwise have joined them..$^{120}$

Although it is clear that individuals listed in blacklists may be seriously harmed by the government's decision to publish such documents, the question remains whether such harm constitutes "punishment" within the ambit of the bill of attainder clause. Unlike the legislative acts thus far declared bills of attainder, all of which entailed direct governmental deprivations, the harm suffered by the victims of blacklisting results from the imposition of private sanctions indirectly encouraged by the government's decision to publish the blacklist.

An extension of the Cummings definition of punishment ${ }^{121}$ to encompass such indirect deprivation is suggested by the Supreme Court decision in NAACP $v$. Alabama. ${ }^{\mathbf{1 2 2}}$ In that case, the court held that the government could not compel exposure of the membership lists of an unpopular organization because it would encourage private sanctions against individuals who had exercised their freedom of expression and association. ${ }^{123}$ Since the mere act of exposing individual names can constitute government deprivation of First Amendment freedoms, and since Cummings stated that "any deprivation or suspension of any ... [inalienable] rights for past conduct is punishment, and can be in no otherwise defined," 124 it would seem that the injuries

119. Bates v. Little Rock, 361 U.S. 516 (1960) (reversing convictions of the NA $\mathrm{Cl}^{\text {' }}$ for failing to comply with an occupational license tax ordinance requiring the production of local branch membership lists); NAACP v. Alabama, 357 U.S. 449 (1958) (reversing a contempt conviction against the NAACP for failure to produce membership lists); Watkins v. United States, 354 U.S. 178 (1957) (limiting Congress' power to compel the disclosure of information during congressional investigations). See Dombrowski v. Pfister, 380 U.S. 479,487 (1965), in which Justice Brennan coined the term "chilling effect" In an opinion that granted federal injunctive relief to plaintiffs who alleged that they would be irreparably injured by harassment and prosecution under an unconstitutional state statute.

120. See NAACP v. Alabama, 357 U.S. 449, 462.63 (1958), in which the Court concluded that disclosure of the membership lists of the NAACP's local branches was

likely to affect adversely the ability of petitioner and its members to pursuc their

collective effort to foster beliefs which they admittedly have the right to advocate,

in that it may induce members to withdraw from the Association and dissuade

others from joining it ....

121. See pp. 208-09 supra.

122. 357 U.S. 449 (1958).

123. Id. at 462-63.

124. 71 U.S. (4 Wall.) 277, 322 (1866). 
peculiar to blacklisting satisfy the bill of attainder requirement of "punishment."125 This conclusion is consistent with the basic purpose of the bill of attainder clause-to prevent deprivations of any kind by legislative action enumerating the individuals to be affected.120

Many blacklists would fall within these broad criteria regarding the specificity of target and the nature and formality of punishment. However, the Supreme Court has not yet created a single, clear definition of attainder encompassing all these criteria, nor have the cases in which legislative acts were held invalid as bills of attainder forced the Court to test the outer limits of this broader model. It seems clear that not all legislative acts that refer in general terms to identifiable groups of individuals and prescribe actions which injure them are bills of attainder -if that were so, a great deal of regulatory legislation would be invalid. ${ }^{127}$ For present purposes, however, the limits on specification are irrelevant-the documents under consideration in this Note are those that either list the actual names of the individuals or organizations attacked or identify them with at least the particularity banned in Brown. ${ }^{128}$ Potential limits on the attenuated concept of punishment, though, are significant in relation to blacklists.

One consideration that might make courts reluctant to extend the concept of punishment to include deprivations resulting from government publication is the desire to preserve the right of critical comment about public figures, which underwent a sweeping expansion during the same period that saw the expansion of the bill of attainder prohibition under Brown.129 If courts were to extend the bill of attainder clause to encompass congressional blacklisting, they would sacrifice some of the unique contributions that Congress, utilizing sources available to it alone, can make to the general debate on public issues and leaders. On the other hand, the very fact that Congress possesses special

125. Private sanctions appear to have been the crucial factor in Justice Black's conclusion that the Attorney General's list of subversive organizations cntailed sufficient government "punishment" to constitute a bill of attainder. See note 104 supra. James Madison also appears to have envisioned the bill of attainder clause as prohibiting legislative censure of specified individuals. See note 101 supra. Bills of attainder utilizing indirect punishment can also be found in early English law. A statute cnacied in the fourteenth century, for example, proclaimed of an attainted person, "he that should bring his head should have $500 \mathrm{l}$. of the King's Gift." See Note, supra note 92, at 1511. 126. See p. 205 and note 93 supra.

127. A regulatory statute explicitly aimed at the nation's strip miners, for instance, might detrimentally affect a small, casily ascertainable group, but it vould probably not constitute a bill of attainder.

128. The statute held invalid in Brown identified its target as any person who is or was during the prior five years a member of the Communist Party. 381 U.S. 437, 438 n.I (1965).

129. See note 24 supra. 
advantages in the marketing of opinion-including extraordinary prestige, access to secret government information, use of the subpoena power, and the absence of effective competition-would seem to justify the imposition of limitations not placed upon the publishing power of private sources of expression. Furthermore, many of the policies that underlie the public comment cases-concern for the rights of individuals to speak out freely on matters of public interest and to petition government for the redress of grievances-do not apply when the source of expression is the lawmaking branch of government. Moreover, Congress and its members are shielded by special constitutional protections not available to any other public speaker. ${ }^{130}$ These considerations suggest that the recent narrowing of common law restrictions on an individual's right of expression should not deter acceptance of a concept of attainder broad enough to encompass congressional blacklisting.

\section{The Element of Intent}

The discussion so far has concerned documents that are in effect bills of attainder and has ignored the possibility that to be constitutionally defective a legislative act must also be motivated by an intent to punish. For many years, this issue was resolved by reference to a series of cases upholding state qualifications for employment, which held that only the clearest proof of an intent to punish would suffice to invalidate a statute as a bill of attainder, and even that would be insufficient if the government could justify its actions in terms of goals other than punishment. ${ }^{131}$

These strict requirements have been modified by the more recent case of United States $v$. Brown. ${ }^{132}$ In that case, the government argued that a law barring recent members of the Communist Party from serving on the executive board of a labor organization was not intended as punishment of the Communist Party or its membership, but rather

130. E.g., the speech and debate clause (Article I, Section 6), the right to publish a journal of proceedings (Article I, Section 5), and the separation of powers doctrinc. SeE note 24 supra.

131. De Veau v. Braisted, 363 U.S. 144, 160 (1960) (law forbidding those convicted of a felony to hold office in a waterfront labor union); Garner v. Los Angeles Bd., 341 U.S. 716, 722-23 (1951) (law barring from city office anyone who, within the last five years, had advocated the forceful overthrow of the state or federal government or had belonged to an organization that did so); Hawker v. New York, 170 U.S. 189 (1898) (law making it a misdemeanor for anyone to practice medicine after having been convicted of a felony). See also Flemming v. Nestor, 363 U.S. 603, 617 (1960) (provisions of the Social Security Act disqualifying selected groups for old-age bencfits).

132. 381 U.S. 437 (1965). 
as a reasonable occupational regulation serving the legitimate interest of national security. The Court did not accept this rationale:

It would be archaic to limit the definition of 'punishment' to 'retribution.' Punishment serves several purposes: retributive, rehabilitative, deterrent-and preventive. One of the reasons society imprisons those convicted of crimes is to keep them from inflicting future harm, but that does not make imprisonment any the less punishment. ${ }^{133}$

Despite this broad definition of "punishment," the Brown Court apparently did not dispense altogether with intent and institute a pure effect test. Since Brown involved a criminal statute, a legislative act that on its face demonstrates an intention to deprive, the Court did not consider whether such an intent is a separate requirement of "punishment" under the bill of attainder clause. That issue is raised, however, by a congressional blacklist, which arguably may have been drafted solely for informational purposes, relegating the resulting deprivation of the right of expression to the status of an incidental and unintended side effect of publication.

Although it did not dispense altogether with an intent requirement, the Brown decision undeniably points in the direction of a pure effect standard. It describes the bill of attainder clause as a flexible prohibition designed to bar legislative acts which in fact, though not necessarily in form, usurp the judicial function. ${ }^{134}$ Furthermore, it so greatly broadens the definition of punitive purposes as to arguably render any deprivational legislative act a bill of attainder. Elimination of the requirement that the deprivation be deliberate, moreover, would comport with a sound construction of the bill of attainder clause. The prohibition against bills of attainder is directed primarily at the vice of explicit specification of the individuals to be affected by legislation. ${ }^{135}$ It would seem unreasonable to permit Congress to circumvent this policy simply by presenting purported non-deprivational purposes for the publication of a blacklist.

This line of argument suggests that congressional blacklists in general-and H.R. 91-1732 in particular-are unconstitutional bills of attainder. Such documents specify certain individuals or organizations, accuse them of illegal or at least generally disapproved behavior, and

135. See p. 205 and note 93 supra. 
regardless of deprivational intent, have the effect of punishing the specified persons by encouraging private hostility and retribution. ${ }^{130}$

\section{B. The First Amendment Claim}

Since the harm flowing from congressional blacklisting is a result of hostility to certain political beliefs and affiliations, persons named in such documents naturally look to the First Amendment for protection. Although it is thought to enjoy a "preferred position" among constitutional provisions, ${ }^{137}$ the First Amendment does not provide an ab. solute bar against infringements upon freedom of speech incidental to government regulation of matters unrelated to expression. ${ }^{138}$ To be successful, a First Amendment challenge to congressional blacklisting must establish (1) that the blacklist threatens the persons named with serious harm of a nature proscribed by the First Amendment, and (2) that such injury is not justified by legitimate government functions.

\section{The Impact of Congressional Blacklisting on First Amendment Rights}

The types of injuries suffered by those named in blacklists-public hostility, loss of employment, and sometimes even personal injury and property damage-as well as the resultant "chilling effect" on the future exercise of rights of expression and of association have already been described. ${ }^{139}$ In response to these dangers, the Supreme Court has held that the government's role in instigating such injuries through disclosure of information constitutes sufficient state action to create

136. If, however, courts demand that an intent to inflict deprivation be proved, such a requirement might still be satisfied by reference to the wording, legislative history, and supporting speeches of a particular blacklist. See pp. 220.23 infra. Cf. Kennedy v. Mendoza-Martinez, 372 U.S. 144, 170-86 (1963), in which examination of those factors led the Court to conclude that a law depriving a certain class of people of their citizen. ship was punitive in nature. See also United States v. O'Bricn, 391 U.S. 367, 383 n.80 (1968), which indicates that an analysis of motivation may be proper in a bill of attainder case and should not be deterred by judicial reluctance to examine motivation in other areas of the law.

137. See United States v. Carolene Products Co., 304 U.S. 144, 152 n.4 (1938) and cases cited in Kovacs v. Cooper, 336 U.S. 77, $90-94$ (1949) (Frankfurter, J., concurring).

138. United States v. O'Brien, 391 U.S. 367, 376 (1968); Watkins v. United States, 954 U.S. 178,198 (1957).

The First Amendment protects individuals against infringements on their rights of expression by "lawmaking" as well as by "laws." Watkins v. United States, 354 U.S. 178, 197 (1957). Like congressional investigations at issue in Watkins, congressional reports issued pursuant to such an inquiry and designed to facilitate drafting and cvaluation of legislation is part of the "lawmaking" subject to the First Amendment's prohibitions.

139. See pp. 209-10 supra. 
an impermissible deprivation of First Amendment freedoms, even though the harm is directly imposed only by private individuals. ${ }^{140}$

Although most of the cases have involved forced disclosure by the injured individual of damaging information, the language and policy concerns of those opinions would appear to forbid indirect infringement of individual rights through government disclosure of unfavorable information regardless of its source. The cases place emphasis not upon state coercion, but upon the interplay between state action and private reaction. Moreover, the primary focus has been the protection of the freedoms of expression and association, which are threatened by the mere disclosure of harmful information, rather than the right against self-incrimination, which is threatened by forced extraction of information. Thus, it would appear that even blacklists compiled solely on the basis of voluntarily disclosed or public information infringe on the constitutional guarantees of freedom of expression and association.

Although disclosure of this type infringes upon First Amendment rights, proof of infringement will not alone establish its unconstitutionality. Indeed, courts will generally uphold those official actions that serve legitimate and important governmental functions. ${ }^{141}$ Those faced with such a claimed justification can pursue two lines of attack. First, an act can be challenged on the ground that it was motivated by a desire to further impermissible governmental purposes. Second, the legitimacy of the goals can be conceded and the act attacked because there exist alternative means of serving the government's legitimnte interests which impose less drastic restrictions on individual rights. These two arguments will be considered in turn to determine the First Amendment limitations on congressional blacklisting.

\section{Legislative Motivation}

The Supreme Court has shown a strong aversion to examining legislative motivation, stemming from three difficulties inherent in such an undertaking. ${ }^{142}$ First, it is extremely difficult to ascertain the mo-

140. Bates v. Little Rock, 361 U.S. 516 (1960); NAACP v. Alabama, 357 U.S. 449 (1958); Watkins v. United States, 354 U.S. 178 (1957); Wallace v. Brewer, 315 F. Supp. 491 (M.D. Ala. 1970) (voiding an Alabama statute requiring that all Mifuslim organizations register with and supply membership lists to the Alabama Department of Public Safety).

141. See note 138 supra.

142. Ely, Legislative and Administrative Motivation in Constitutional Low, 79 Yale L.J. 1205, 1212-17 (1970). See also Palmer v. Thompson, 403 U.S. $217,224.25$ (1971) United States v. O'Brien, 391 U.S. 367, 385 (1968). The terms "bad," "illicit," and "illegitimate" motivation will be used interchangeably to describe constitutionally impermissible purposes. 
tivation behind a particular congressional act, if indeed it even makes sense to speak of discrete motives when dealing with a large number of individual legislators, each of whom may have a variety of different reasons for supporting a particular act. Since the respect owed a coordinate branch of government requires that a congressional act only be overturned upon a substantial showing of illegality, ${ }^{143}$ the Court is and should be most reluctant to void such an act upon the usually ambiguous proof of bad motivation. Second, an act which has been found unconstitutional on the grounds of illicit motivation can be repeated with impunity if the legislators are simply more careful the second time to avoid statements suggesting such impropriety. This consideration is particularly important in injunction suits in light of the judicial policy against futile judgments by a court in equity. ${ }^{144}$ Third, it can be argued that an act that is otherwise unobjectionable should not be invalidated solely because of the objectionable statements and mo. tives of a few of its supporters. ${ }^{145}$

The Supreme Court's policy towards examination of legislative motivation prompted by these concerns is revealed in two separate lines of precedent. In cases challenging legislative investigations as improperly motivated, the Court has repeatedly held that illegitimate motivation will not alone vitiate an investigation that serves legitimate purposes. ${ }^{146}$ Yet, it has not ruled out entirely analysis of motivation in such cases, insisting that a legislature is without authority to "expose for the sake of exposure."147 This suggests that proof of illicit motivation would be sufficient to invalidate an investigation at least in cases where no legitimate explanation was presented. The Court, how-

143. Flemming v. Nestor, 363 U.S. 603, 617 (1960); Fletcher v. Peck, 10 U.S. (6 Cranch) 87, 128 (1810).

144. See New York Times Co. v. United States, 403 U.S. 713, 744 (1971) (Marshall, J., concurring); Z. Chafee \& E. RE, EQuity $935-54$ (5th ed. 1967); 1 H. Joyce, InJunctions $\S \S 58-60 \mathrm{a}(1909)$.

145. But see Brest, Palmer v. Thompson: An Approach to the Problem of Unconsti. tutional Legislative Motive, 1971 Sup. Cr. REV. 95, 115.31 (1971), in which the author balances the arguments for and against the judicial examination of motivation and concludes that "[a] court should entertain an action challenging an otherwise constitu. tional decision ... on the ground that it was designed in part to serve an illicit or suspect objective." Id. at 130 .

146. Hutcheson v. United States, 369 U.S. 599 (1962); Braden v. United States, 365 U.S." 431 (1961); Wilkinson v. United States, 365 U.S. 399 (1961); Barenblatt v. United States, 360 U.S. 109 (1959); Watkins v. United States, 354 U.S. 178 (1957).

147. Watkins v. United States, 354 U.S. 178, 200 (1957). See also Hutcheson v. United States, 369 U.S. 599 (1962), in which the Court upheld a Senate Committec's right to investigate certain activities on the grounds that such inquiry was within the scope of Congress" legitimate functions and because "the record is barren of cvidence indicating that the Committee, for reasons of its own, undertook to 'expose' this petitioncr." Id. at 617 . 
ever, has never held a legislative inquiry invalid on the basis of this "exposure" principle. ${ }^{148}$

In considering motivation attacks on legislative enactments, the Court has established a general rule against examination of legislative motivation. In United States $v . O^{\prime}$ Brien, ${ }^{120}$ a challenge to a Selective Service law amendment prohibiting the destruction of draft cards on the ground that Congress enacted it in order to stifle anti-war dissent, the Court explicitly declined to examine motivation and instead promulgated the following rule:

A government regulation is sufficiently justified if it is within the constitutional power of the government; if it furthers an important or substantial government interest; if the government interest is unrelated to the suppression of free expression; and if the incidental restriction on alleged First Amendment freedoms is no greater than is essential to the furtherance of that interest. ${ }^{150}$

At least in cases not involving the establishment of religion clause, ${ }^{151}$ the Court claims that it has always adhered to this strict effect test. ${ }^{152}$ However, at least three earlier cases cannot be easily harmonized with this rule. In Grosjean v. American Press Co., ${ }^{103}$ voiding a tax on news-

148. In DeGregory v. Attorney General, 385 U.S. 825 (1960), the Court declared unconstitutional the forced extraction of information about communist affiliations by the New Hampshire Attorney General on the ground that the state had failed to prove that it was in any real danger of subversion. The Court purported to avoid the motivation issue by finding that the inquiry was not justified by any "compelling state interest." Id. at 830 .

Other legislative investigations have been declared unconstitutional because their interrogations exceeded the scope of inquiry established by a parent body, Sacher v. United States, 356 U.S. 576 (1958); United States v. Rumely, 345 U.S. 41 (1953); cf. Swcez; v. New Hampshire, 354 U.S. 234 (1957); or by its own official statement of intention. Gojack v. United States, 384 U.S. 702 (1966); Deutsch v. United States, 367 U.S. 456 (196I); Scull v. Virginia, 359 U.S. 344 (1959).

149. 391 U.S. 367 (1968).

150. Id. at 377 . The last criterion is essentially a restatement of the "less drastic means" test discussed at pp. 223-25 infra.

151. Although the Court has never said that religion cases constitute a special cxception to the bar against examining motivation, it is difficult 10 construc these cases oth. erwise. In Abington School District v. Schempp, 374 U.S. 203, 222 (1963), in overtuming a Pennsylvania statute that required the reading of passages from the Bible in public schools, the Court established the rule that if a law's "purpose" or "primary effect" is to advance religion, that law is an unconstitutional establishment of religion. In 1968, immediately after $O^{\prime} B r i e n$, the Court twice again examined motivation in religion cases -Board of Educ. v. Allen, 392 U.S. 236 (1968); Epperson v. Arkansas, 393 US. 97 (1968)and in the latter case invalidated the statute solely on the ground that it was motivated by a pro-religion animus. One can conclude only that the Court is villing to consider motivation in cases dealing with one section of the First Amendment (establishment of religion) but not in cases dealing with another section (freedom of specch), although the reason for this distinction remains unexplained and, one suspects, is incxplienble.

152. Palmer v. Thompson, 403 U.S. 217, 225 (1971); United States v. O'Brien, 391 U.S. 367, 384-85 (1968).

153. 297 U.S. 233 (1936). The Court found that the tax had "the plain purpose of penalizing the publishers and curtailing the circulation of a selected group of nevispapers," in violation of their First Amendment freedom of the press. Id. at 251. 
papers with a circulation of over 200,000 copies per week, Gomillion v. Lightfoot, ${ }^{154}$ invalidating a new twenty-eight-sided municipal boundary that excluded virtually all black residents from the city limits, and Griffin v. County School Board of Prince Edward County, ${ }_{2}^{155}$ invalidating the closing of all of the county's public schools to avoid their desegregation, the Court explicitly considered government motivation and seemed to rely on its finding of improper motive in holding the actions unconstitutional. ${ }^{156}$ These three cases seem to stand for the proposition that illicit legislative motivation may be so easy to ascertain in certain situations ${ }^{157}$ that courts are justified in abandoning their normal reluctance to examine motivation and in declaring an act unconstitutional on the basis of that motivation. ${ }^{168}$ However, in the most recent case on the subject, Palmer $v$. Thompson, ${ }^{150}$ the Court rejected this interpretation. While admitting that cases like Gomillion and Griffin appear to find motivation relevant to the constitutionality of government enactments, the Court maintained that the principal focus of even those cases was on effect rather than motive, and it reaffirmed the $O^{\prime} B r i e n$ rule that bad motivation will not invalidate a legislative act that can be justified in terms of legitimate purposes. ${ }^{160}$

154. 364 U.S. 339 (1960). The Court held that the new boundary deprived blacks of their right to vote in violation of the Fifteenth Amendment.

155. 377 U.S. 218 (1964).

156. See discussion in T. EMERson, THE System of Freedom of Expression 419 (1970); Ely, supra note 141, at 1209, 1331-34. For another First Amendment case in which mo. tivation appears to have played a role, see Oestereich v. Selective Service Bd., 393 U.S. 233 (1968) (dictum that draft reclassification for the purpose of punishing anti-war pro. testors is unconstitutional).

157. Bad motivation may be comparatively easy to ascertain when the method chosen by the legislature to further its professed goals is particularly unusual_-like the drawing of a twenty-eight-sided municipal boundary or the closing of all schools in one district in a state-or when there exists an unusual amount of evidence indicating such bad motivation, as was probably true in Grosjean. But see Ely, supra note 142, at 1332.33, in which the author discusses some of the compelling evidence of illicit intent in Grosjean but concludes that such evidence should not alone suffice to void a statute.

158. In a recent critique of the Court's approach to legislative motivation, Professor Paul Brest suggests that proof of illicit motivation should always be deemed relcvant to a challenge to the constitutionality of a legislative act. He contends that such an act should be declared unconstitutional if the complainant can "establish by clear and convincing evidence that [an illegitimate] objective played an affirmative role in the decision-making process." Brest, supra note 145, at 130-31. This formula would obviously produce results different from those dictated by the $O^{\circ} B$ rien rule, and might prove helpful in understanding the Court's decisions in Gomillion, Griffin, and Grosjean. Com. pare Ely, supra note 142 .

159. 403 U.S. 217 (1971).

160. Id. at 225. In Palmer, the Court upheld Jackson, Mississippi's decision to close down its public swimming pools instead of allowing them to be integrated, ostensibly because they could not be run economically on an integrated basis, becattse Jackson hat shown the required legitimate justification and its action did not treat blacks differently from whites. Although the Palmer Court tried to distinguish Griffin on the ground that there the state had gone beyond merely closing public facilities and had supported 
In its own interpretation of the case law, the Henloff court concluded that the Supreme Court's general warnings against probing into motivation did not bar a finding of "exposure for exposure's sake" as to an act of disclosure for which no legitimate purposes existed. The court found that the publication of H.R. 91-1607 (the original version of H.R. 91-1732) was such an act, as proved by the report's failure to recommend any specific legislation and its admission that its findings could not establish a connection between campus speaking engagements and the financing of subversive organizations. ${ }^{101}$ The court concluded that the only conceivable purpose for publishing the report was the illegitimate one of encouraging private sanctions against the listed speakers. ${ }^{102}$ These conclusions and the finding that the report had a chilling effect upon the speakers' First Amendment rights were deemed sufficient to justify issuance of the requested injunction against publication of the report.

This reasoning entails serious difficulties. The Henloff court made the case easy by concluding that no legitimate function could have been served by publication of H.R. 91-1607. But that conclusion does not seem justified. Even granting that the evidence amassed in H.R. 91-1607 was of highly questionable value and that the report's authors admitted their inability to establish any connection between the listed speakers and the funding of allegedly subversive organizations, it would still appear to be beyond the competence and proper function of a court to determine that no Congressman could find the report of any use in drafting legislation, which is H.R. 91-1607's avowed and undeniably legitimate purpose. ${ }^{103}$ No rule exists, nor should one be established, that requires Congressmen to base their legislative decisions only upon facts and opinions exhibiting a judicially approved level of accuracy or completeness. Nor does it seem advisable to insist that only those reports that recommend specific pieces of legislation can form part of the pool of information upon which legislators may act. Even the recitation of the individuals' names and the amounts of their honoraria, while not absolutely essential to the legislative process, would undoubtedly contribute to the decision of at least a few Congressmen to support or oppose future legislation

private schools that discriminated, it is difficult to ignore the Griffin opinion's explicit finding of illicit motivation and the similarity of the fact patterns in Griffin and Palmer. For an extended critique of Palmer see Brest, supra note 145, at 95-102.

161. H.R. 91-1732, at 10 .

162. Hentoff v. Ichord, 318 F. Supp. 1175, 1182 (D.D.C. 1970).

163. H.R. 91-1732, at 2 . 
on "subversives." Similarly, such specificity in the legislative history might assist the executive in administering the resulting legislation or the judiciary in interpreting its function and scope. Finally, specific information in congressional reports might contribute to the public's understanding of the operation of congressional committees and to its ability to evaluate legislation and legislators.

Given this set of significant and legitimate governmental purposes, there would appear to be little basis under the existing case law for enjoining most congressional blacklists on the ground of improper motivation. Like disclosure through committee investigations, publication of committee reports can always be defended by reference to the general utility of information, unless in an unusual case like DeGregory v. Attorney General ${ }^{104}$ the court can honestly find that nothing in the subject matter of the inquiry serves a proper legislative purpose. The few statutory cases that examine motivation do not suggest a contrary conclusion. For while some blacklists may be published under circumstances which provide such undeniable proof of bad motivation that courts, following Grosjean, Gomillion and Griffin, might feel justified in enjoining them on that ground alone, a careful legislature could easily avoid that pitfall. ${ }^{105}$ Furthermore, the Court is unlikely to retract its repeated claim that these cases do not represent exceptions to the $O^{\prime} B r i e n$ rule. ${ }^{106}$

Although these strict requirements indicate that most congressional blacklists will not be found unconstitutional solely on the basis of bad motivation, the Hentoff report itself may constitute one of those few blacklists which should be enjoined on that basis. The report involved in that case contains within its official text a statement which provides particularly clear evidence of illicit motivation. Both versions of the report state:

The Committee believes that the limited sampling [in this survey] is sufficient to alert the Congress, college and university administrators, faculty, alumni, students, and parents to the probable extent of campus guest oratory in promoting the radical, revolutionary movement. ${ }^{167}$

164. 385 U.S. 825 (1966). See note 148 supra.

165. The authors of the Hentoff report, however, were not so careful, as the quotation on this page indicates.

166. See pp. 217-18 supra.

167. H.R. 91-1732, at 16 . 
This statement, read in the context of the report's description of student violence and campus bombings, can only be seen as an appeal for those involved in the control of educational institutions to take action against radical campus speakers. This is a blatant encouragement of sanctions, an undertaking forbidden by the First Amendment.108 Unlike the recorded statements of any single drafter of that document, such an appeal written into the report itself gives the formal approval of the entire committee, and indeed of the entire House of Representatives which passed a resolution to publish H.R. 91-1732, to a straightforward statement of illegitimate motivation. Not only does this passage offer powerful proof of unconstitutional motivation, but it would also presumably increase the potential harm to plaintiffs by stamping private retribution with official government approval.

This problem of written proof of illicit motivation within the text of an otherwise lawful legislative document was confronted recently by the California Supreme Court. In Parr v. Municipal Courl, ${ }^{100}$ the court voided a municipal ordinance of the City of Carmel prohibiting, among other things, sitting on the grass in the village park, solely because of a preambular "statement of urgency" which proclaimed that the law had been passed because of "an extraordinary influx of undesirable and unsanitary visitors to the city, sometimes known as "hippies." "170 The court ruled that this ordinance violated the right of those whom the Carmel authorities deemed to be "hippies" to the equal protection of the laws for two independent reasons: (1) a statement within a law which appears officially to encourage the infliction of deprivation upon a certain group is likely to foster discriminatory enforcement of that law against that group; and (2) a statement of intent written into a government document can provide a sufficiently reliable indication of bad motivation to overcome the normal judicial reluctance to examine legislative intent and suffice to render it unconstitutional as a deliberate deprivation of individual rights.

It is not clear how such written proof of illicit motivation would affect the outcome under the O'Brien test. The Hentoff court, as we have seen, held that the offending sentence is further proof that H.R. 91-1607 had no legitimate purpose. However, as suggested above, ${ }^{171}$

168. See pp. 214-15 supra.

169. 3 Cal.3d 861, 479 P.2d 353, 92 Cal. Rptr. 153, cert. denied sub nom. City of Carmel-by-the-Sea v. Parr, 404 U.S. 869 (1971).

170. 3 Cal.3d at 863,479 P.2d at 354,92 Cal. Rptr. at 154.

171. See pp. $219-20$ supra. 
legitimate purposes can be found for the report in general, and it is questionable whether the Supreme Court would either find that a single sentence negates the claim of good intentions or, if so finding, conclude that the legislature is held to its stated purposes even if other proper ones can be conceived of by the reviewing court. 172

It can be argued, however, that written proof of bad motivation, even if found only in a single sentence, should be sufficient to render a congressional action unconstitutional. It must be remembered that the reluctance of the judiciary to examine legislative motivation is based upon the three considerations discussed above-ascertainability, futility, and disutility ${ }^{173}$-all of which assume far less importance when a claim of bad motivation is supported by written proof in the text of the challenged document. While an institutional desire to "expose for exposure's sake" may not be properly ascertained on the basis of speeches given by only a few of the men who supported the challenged document, a statement of bad motivation in the text of the document itself carries with it, at least by implication, the endorsement of every Congressman who voted for its publication. The argument of disutility is similarly weakened. While it would be unwise to invalidate congressional action that has no harmful effects simply because an objectionable speech was made on its behalf, a written statement of illicit intent may, as the Parr court explained, itself increase the harmful effects of an action by offering governmental endorsement of the sentiments expressed in that statement. ${ }^{174}$ The claim of futility can also be countered. While it may be futile to reject a document solely because of speeches made in its defense (since Congress can merely resubmit the document after cautioning its supporters to make wiser speeches), a report with an offending passage in its text cannot be resubmitted exactly in its original form. At the very least the offending passage must be deleted, somewhat changing the substance, form, and even the impact of the report. Furthermore, the entire

172. See Ely, supra note 142 , at 1276-78. See also Lassiter v. Northampton County Bd. of Elections, 360 U.S. 45 (1959), in which the Court upheld a literacy test as a qualifica. tion for voting against a claim of bad motivation despite the fact that the challenged state constitutional provision also included a clearly illegal "grandfather clause" and a statement that the entire provision constituted "one indivisible plan for the regulation of the suffrage." N.C. CoNsr. art. VI, § 5. However, the literacy test and grandfather clause still represented two separate voting qualifications, while the statement of urgency in Parr and the offending paragraph in Hentoff were avowedly statements of purposes for the documents as $a$ whole, and thus provided far better proof as to the motivation behind all sections of those documents.

173. See pp. 215-16 stepra.

174. 3 Cal.3d at $868-69,479$ P.2d at 358,92 Cal. Rptr. at 158. 
argument of futility should be seriously questioned: it is never truly futile to vindicate a valid constitutional principle, and perhaps a judicial reprimand, even when applied in response to mere supporting speeches, might encourage some Congressmen to reconsider the wisdom of the entire document involved. ${ }^{175}$ The city of Carmel, it should be noted, substantially diluted its ordinance when re-enacting it after the Parr decision..$^{176}$

\section{Less Drastic Means}

Although some documents, like H.R. 91-1732, which contain written proof of bad motivation may be subject to injunction, it seems clear that proof of an impermissible motivation will not invalidate the great majority of congressional blacklists. Courts have, however, developed another limitation on governmental actions, the less drastic means test, which is specifically designed to deal with situations in which the government can present legitimate justifications for actions that indirectly infringe constitutional rights.

The less drastic means test examines a government act not in terms of the motivation prompting it but rather in terms of its objective effects. As traditionally interpreted, it provides that a government act may be found unconstitutional if its incidental restriction of First Amendment rights is greater than is necessary for the accomplishment of the government's legitimate purposes. ${ }^{177}$ Put another way, the government may be required to choose a method of achieving its ends

175. Professor Paul Brest goes further and suggests that when the decision of a government body is accompanied by sufficient indicin of bad motivation to varrant a declaration of unconstitutionality, "the court should enjoin [that body] from making the same decision again unless [it] comes forward with persuasive cridence that this time it will be made only for legitimate reasons." Brest, supra note 145, at 126. But sce Parr v. Municipal Court, 3 Cal.3d 861, 873-74, 479 P.2d 353, 362, 92 Cal. Rptr. 153, 162 (1971) (Burke, J., dissenting).

176. On December 8, 1971, the city of Carmel enacted a new ordinance embodying many of the provisions in the law voided by Parr. CAmaec.-nY-THE-SEA, CiL. MfUsicirai. CoDE $\$ \$ 697.01,697.02$ (1972), formerly Carmel-by-the-Sea, Cal., Ordinance 173 CS., July 31, 1968, as amended, Ordinance 175 C.S., Aug. 7, 1968, and Ordinance 215 C.S., March 4,1970 . However, the statement of urgency was dropped altogether, no mention of "hippies" is made in the new ordinance, and the provisions which vould have proved most onerous to such visitors-criminal sanctions for sitting on the grass and steps of the city park-have been altered to forbid only walking on the lawns during secding time. In other words, the fears of the dissenters in Parr vere unfounded: Carmel has been able to fashion a new ordinance for the protection of its natural beauty while eliminating those sections of the old law which most directly threatened to turn it into a vehicle for the persecution of "hippies." Copies of the old and new ordinances are on file with the Yale Law Journal.

1'j7. Shelton v. Tucker, 364 U.S. 479, 488 (1960). See also Richardcon, Freedom of Expression and the Function of the Courts, 65 HaRv. L. REv. 1, 23-24 (1951); Note, Legislative Inquiry into Political Activity: First Amendment Immunity from Commiltee Interrogation, 65 YALE L.J. 1159, 1173-75 (1950). 
which inflicts a less drastic infringement on the First Amendment rights of its citizens. Indeed, this rule was expressly re-affirmed in $O^{\prime} B$ rien, ${ }^{178}$ although its cursory application may well have altered the outcome of the case.179

Although the Supreme Court is often hesitant to characterize its reasoning as a balancing process, any evaluation of the reasonableness of a legislative method will inevitably involve a comparison of the values and costs of the alternative courses of action. As one commentator has observed, however, what actually occurs in these cases is not a broad balancing of the fundamental values involved (e.g., national security versus free speech) but rather a more limited balancing of "the state's interest in the added effectiveness of the chosen means against the individual interest in the use of less drastic ones." 180 Thus, in the leafletting cases, ${ }^{181}$ the Court's decision to overturn statutes which banned the distribution of leaflets did not sacrifice entirely the governmental interest in litter-free streets, but only imposed the slight additional cost of using other means of solving the litter problem (such as criminal sanctions against litterers) which have a less drastic effect on public expression.

In order to perform such balancing in an intelligent manner, courts need some idea of the available alternatives. It thus seems inadequate for a court simply to evaluate the challenged course of action, find it too drastic on its face, and then return the issue to the legislative arena. ${ }^{182}$ On the other hand, the need to consider alternative approaches does not require usurpation of the legislative function of selecting the best method. ${ }^{183}$ The most satisfactory approach,

178. 391 U.S. at 377. See p. 217 supra.

179. See Ely, supra note 142, at 1340-41.

180. Note, Less Drastic Means and the First Amendment, 78 YaLE L.J. 464, 468 (1969).

181. Marsh v. Alabama, 326 U.S. 501 (1946); Schneider v. State, 308 U.S. 147 (1939).

182. This is essentially what the Court did in United States v. Robel, 389 U.S. 258, 267 (1967), in which it used the less drastic means test to overturn a federal statite making it a criminal offense for a member of a "communist-action organization" 10 engage in any employment in a defense facility. The Court stated:

The Government has told us that Congress, in passing [this statute], made a con. sidered judgment that one possible alternative to that statute-an industrial sccurity screening program-would be inadequate and ineffective to protect against sabotagc in defense facilities. It is not our function to examine the validity of that congres. sional judgment. Neither is it our function to determine whether an indtstrial screening program exhausts the possible alternatives to the statute under review. We are concerned solely with determining whether the statute before us has cxceeded the bounds imposed by the Constitution when First Amendment rights are at stake. The task of writing legislation which will stay within those bounds has been committed to Congress.

183. Courts of equity clearly have the power to suggest specific procedures for the coordinate branches of government and even, under limited circumstances, to command compliance with such suggestions. In Miranda v. Arizona, 384 U.S. 436, 444, 455 (1966), 
therefore (and the one usually followed by the Court), is for a court to consider the incremental costs and benefits of the various suggested alternatives ${ }^{18 t}$ and, if it finds any of them to be less drastic than the challenged action, declare the latter unconstitutional, without imposing a particular alternative.

In applying less drastic means analysis to government publication of congressional blacklists, courts will have to evaluate the impact of both the challenged action and the suggested alternatives upon the interests of the government and the affected individuals. On the one hand are the basic harms created by such documents: they encourage the infliction of sanctions upon individuals whose only objectionable acts may have been the exercise of constitutionally protected rights of expression and association, and they "chill" the willingness of people-blacklisted and unblacklisted alike-to exercise those rights in the future. ${ }^{185}$ On the other are the legitimate governmental functions served by even blacklist-type reports: they provide Congressmen, officials of the coor-

for example, the Court listed specific procedures to be followed by police during the interrogation of suspects in custody, rather than mercly declaring existing practices unconstitutional and allowing the executive or legislature to develop new procedures.

Such judicial specification of procedures for the other branches is, hovever, usually; limited to circumstances in which vital individual rights are threatened by government inaction, that is, unwillingness to correct a constitutionally defective practice. In the landmark reapportionment case of Reynolds v. Sims, 377 U.S. 533 (1964), the Court affirmed a district court's power to impose its own temporary plan for the reapportionment of Alabama's state legislature after the legislature itself had failed to produce a constitutionally acceptable plan. The Court has even tacitly accepted the principle that legislative inaction may justify the imposition of permanent court-dercloped reapportionment plans by its failure to reject district court action in such cases as Parsons $v$. Buckley, 379 U.S. 359 (1965), and Williams v. Moss, 378 U.S. 558 (1964). See Note, The Case for District Court Management of the Reapportionment Process, 114 U. PA. L. REv. 504 (1966).

Similar court proposals in the absence of legislative action have been accepted in the field of public school desegregation. See, e.g., Swann v. Charlotte-Arecklenburg Bd. of Educ., 402 U.S. 1 (1971) (affirming district court's right to appoint an cxpert to develop a desegregation plan and to impose that plan when the school board failed to provide its own acceptable proposal); Bradley v. School Bd., 40 U.S.L.W. 2446 (E.D. Va. Jan. 5 , 1972) (ruling that existing plans to desegregate public schools in the Richmond area had failed to comply with constitutional standards and ordering that the city and two county school districts be consolidated); Hobson v. Hansen, 269 F. Supp. 401 (D.D.C. 1967), aff'd sub nom. Smuck v. Hobson, 408 F.2d 175 (D.C. Cir. 1969) ('freedom of choice" system declared inadequate and busing ordered among District schools).

184. Several methods are available for insuring the formulation of alternatives. Courts could place the burden of proof on one of the parties-either requiring plaintiffs to prove the existence of a viable, less drastic means or demanding that the governmental defendant bear the burden of disproving the existence of such a method. Note, supra note 180 , at 474 . Although avoiding judicial performance of legislative tasks, both of these procedures unnecessarily restrict judicial analysis to options conceived by the party shouldering the burden of proof and waste party efforts in establishing as facts mere policy proposals. It would seem both more efficient and more useful to the decisionmaking process if judges were to consider all possible alternatives-whether sug: gested by a party, an amicus curiac, a legislator, or the judge himself-that would arguably accomplish the government's goals.

185. See pp. 209-10 supra. 
dinate branches of government, and the general public with information which may be useful in the lawmaking process. ${ }^{180}$

As noted, a less drastic means analysis of a course of action requires comparison with alternative possibilities. Several are available. First, a congressional report given general public distribution could be pub. lished without listing the names of specific individuals or groups if a serious infringement of First Amendment freedoms would otherwise result. ${ }^{187}$ A report which excluded such names could also be printed in the Congressional Record, if Congress wished to do so. Second, the report could be printed in full, complete with whatever names are deemed necessary to substantiate its findings, but distribution would be limited to the members of Congress. The text of the report, under this option, would not be placed in the Congressional Record. Third, two different versions of the report could be prepared for independent publication: one containing whatever names are necessary, to be distributed to Congressmen and their staffs; and the other without specification of individuals and groups, to be distributed to all other recipients, includ. ing members of the public. If desired, this version could be included in the Congressional Record as well. ${ }^{188}$

These options represent alternatives to the full publication of congressional blacklists that would greatly reduce the threat to individual liberties posed by such documents. Under the less drastic means test, such unregulated blacklisting must be declared unconstitutional unless it can be shown that each of these alternatives would result in such a decline in the effectiveness with which the legitimate functions of Congress could be pursued as to outweigh, in some sense, the threatened infringement upon personal rights. An analysis of the effects of

186. See pp. $195-96$ supra.

187. To conform with the bill of attainder cases, individuals and groups would also not be described with such particularity as effectively to reveal their identities without actually naming them. See United States v. Brown, 381 U.S. 437, 442, 449.51 (1965).

188. Congress could adopt any of these three options with regard to the independent publication of reports but permit the entire text of the report, including names, to be placed in the Congressional Record for general distribution. This last alternative would be acceptable only if courts were to interpret the journal of proceedings clause to bar all judicial interference with the publication and distribution of the Congressional Record. Although this final option would severely limit the effectiveness of an injunction against the separate publication of a report, it would not render such an injunction wholly futile. Some people who would have read the report will fail to read the Record, others will obey the spirit of even a partial injunction and be dissuaded from privately distributing the report, and still others will consider it "tainted" by judicial condem. nation and thus less reliable. However, since full publication in the Record would be tantamount to congressional evasion of a court injunction, and since courts probably do have the power to prevent such evasion, see p. 204 supra, this alternative will not be considered further. 
the alternatives upon the three informational functions served by congressional reports ${ }^{189}$ indicates that at least two of these options would produce such minimal costs as to render them "less drastic" under any scheme of value measurement.

Under all three alternatives, legislators would have the benefit of the entire report for both the drafting and evaluation of appropriate legislation..$^{190}$ The only interference with the lawmaking process would result from the inability of the legislators to get "feedback" from their constituents. This, however, would only be a significant interference with the legislative function under the second option, which would keep the entire report out of public circulation. Constituent response would not be significantly altered or decreased if the public did not know the actual names of those accused of wrongdoing, so long as the existence of that general type of wrongdoing is publicized.

The executive and judicial branches would also be largely unaffected by a restriction on their access to the names listed in congressional reports. The function of those branches is to interpret legislation so that it may be properly enforced. Insofar as they must go beyond the text of the statute to understand the exact scope of activities that the legislature intended to regulate, they need no more than the general descriptions provided by most congressional reports and floor debates. For that reason, however, the second option-which would exclude extra-congressional distribution-would be very costly, in essence destroying a major segment of the legislative history of statutes based on the reports in question.

The inability of the general public to view the full factual substantiation for certain reports may entail more serious costs. The interference with the public's "right to know"101 that would result from the excision of names from a congressional report would not itself be significant, both because the great bulk of the report's factual findings could be published without specification of names and because it is extremely doubtful whether the excised material could itself properly be considered vital to public evaluation of government. ${ }^{102}$ Yet a lack

189. See pp. 195-96 supra.

190. Although publication of the names would be entircly excluded under the first option, it is hard to imagine that the offensive information vould not be made in. formally available to all Congressmen by the committee members who prepared the report.

191. For a discussion of the "right to know" doctrine, see Hennings, supra note 74 . See also New York Times Co. v. United States, 403 U.S. 713 (1971).

192. More likely, the information would be sought for the very reason that its pub. lication might be thought illegitimate-to expose and punish individuals holding un. popular beliefs. 
of specification in a report distributed to the public might lessen the impact of the report (and thus the perceived need for subsequent legislation) and might also reduce the credibility of the report, its authors, or government in general. This problem is well illustrated by the Hentoff document; for the very listing of specific speakers that infringed upon First Amendment freedoms also supplied the committee's findings with vivid evidence which could hardly have been equalled by the vague claim that sixty-five unnamed but known revo. lutionaries had recently spoken on several college campuses. Yet the loss of both impact and credibility could be substantially reduced if the reason for the lack of substantiation-protection of individual rights-were set forth in the published version. Indeed, congressional reports are frequently kept confidential for a variety of reasons, often touching upon matters of national security, and their lack of credibility among elements of the population is due only to the apparent overuse of that label, a problem as yet unknown in the free speech area. Finally, these costs must be considered in context: only a few reports can be termed blacklists and only a very small part of the information in such documents need be excised to eliminate the threat to individual expression.

Given that under the first and third options there would be essen. tially no interference with the legitimate lawmaking functions of the various branches of government and at most a speculative effect on public respect for government, ${ }^{193}$ it would seem that there are viable alternatives imposing less drastic infringements on First Amendment freedoms ${ }^{194}$ which would require an injunction against full publication of congressional blacklists.

A final argument against restraining the publication of congressional blacklists touches upon the doctrine of futility, for "[i] $\mathrm{t}$ is a traditional axiom of equity that a court of equity will not do a use-

193. The only other cost under the third option would be the fairly minimal expense of publishing a second version of a report with the harmful section or appendix simply deleted.

194. Although this Note deals only with the infringement of First Amendment frcedoms and violation of the bill of attainder clause, it is possible that other rights might be sufficiently threatened by blacklisting to justify the deletion of names in government documents. See Wisconsin v. Constantineau, 400 U.S. 433 (1971) (right to due process of law); Doe v. McMillan, No. 71-1027 (D.C. Cir. Jan. 20, 1972) (Wright, J., dissenting) (right to privacy). A privacy claim, however, is likely to be of little avail to public figures blacklisted because of acts of public expression. The due process claim, morcover, would seem inapplicable to legislative activity since the bill of attainder clause bars any depri. vational specification regardless of the procedure followed. 
less thing." 195 In an ideal world, perhaps, the fact that a court has banned the publication of certain harmful information would completely prevent its disclosure. In reality, however, there are several ways in which information collected by a congressional body might be released. At one extreme, Congress could simply defy the court order and publish the offending material, as it chose to do after the Hentoff ruling by the resounding vote of 302 to $54 .{ }^{100}$ Moreover, any Congressman or congressional agent could obtain a copy of an enjoined report and publish it privately at his own expense, ${ }^{107}$ or accomplish virtually the same result by releasing it to the press. Although such an act might subject the individual who released the report to a libel suit, ${ }^{198}$ it probably would not be termed an official act of Congress and would therefore be free from injunction based upon the First Amendment and bill of attainder arguments presented above. ${ }^{199}$

Even granting these difficulties, however, an injunction against the official publication of a blacklist would be far from the "useless thing" forbidden by the doctrine of futility. It cannot be assumed that Congress will choose to make a practice of defying court orders by publishing enjoined materials, and the judiciary may not guide its decisions by such an assumption. ${ }^{200}$ The private publication or release of enjoined reports may well be deterred effectively by a combination of moral suasion and the threat of personal suits. Together, these factors should substantially curtail the public disclosure of harmful information. Furthermore, as noted earlier, ${ }^{201}$ part of the harm of a blacklist lies in its official nature, in the fact that a derogatory statement appears to enjoy the imprimatur of the government. Yet no official publication of an enjoined report could occur unless Congress were to violate the express terms of the injunction. Finally,

195. New York Times Co. v. United States, 403 U.S. 713, 744 (197I) (Marshall, J., concurring).

196. 116 CoNG. REc. HII624-25 (daily ed. Dec. 14, 1970).

197. Presumably, use by an agent of the official franking privilege to distribute privately published documents would render him liable to private suit. The speech and debate clause would provide no protection either because the agent was not authorized to use the privilege for that purpose or because he was not acting in the capacity of a confidential aide involved in the legislative process. See pp. 198.202 supra. Eicn a Congressman might be subject to injunction, since such use of his franking privilege is arguably beyond his "role" and "power." See pp. 194-95 supra.

198. See note 24 supra.

199. See Note, 46 N.Y.U. L. REv. 606, 612-13 (1971)

200. See MCPherson v. Blacker, 146 U.S. 1, 24 (1892), in which the Court said that it is an "inadmissible suggestion" that action might be taken in disregard of a judicial decision.

20'. See pp. 221-22 supra. 
the legal and moral authority of a court injunction cannot be ig. nored. If the publication of certain types of harmful information is enjoined, Congressmen may be less likely in the future to attempt to publish blacklists.

While these practical considerations are not irrelevant, the primary judicial concern should still be the balance of harm to individual liberties against the impairment of legitimate legislative functions. It cannot be denied that judicial limitations on the publishing power of Congress-either by forcing the use of alternative procedures which satisfy the less drastic means test or by declaring specific blacklists to be ill-motivated or bills of attainder-would, to some degree, impair the efficient operation of the legislature. Moreover, it would limit the important contribution that Congress can and should make to the general public discussion of persons and events of national significance. These costs need not be large, however, to protect fully the First Amendment rights threatened by blacklisting. They are not too great a price to pay in order to prevent substantial harm to affected individuals and to place some reasonable limitations upon the power of Congress to publish blacklists. 